\title{
A closer look at Negative Concord in Afrikaans
}

\section{Theresa Biberauer}

Linguistics Department, Cambridge University, Sidgwick Avenue, Cambridge, CB3 9DA

E-mail:mtb23@cam.ac.uk

\section{Introduction}

An often noted fact about Afrikaans is that it is a Negative Concord (NC) language which, quite unusually among languages of this kind, employs two superficially identical negators (nie... nie) wherever a negated structure does not involve specially designated n-words (e.g. niks - "nothing", nooit - "never"). This is illustrated in (1).

(1) Ek ken nie daardie man nie

I know not that man not

"I don't know that man"

As (1) shows, the two nies do not cancel each other out the way one would expect them to in a non-NC language like English - cf. He did not not know that man, which means that he did know him (i.e., negative + negative $=$ positive) in the corresponding Afrikaans case, the two nies result in a single negation. A further notable, but not often noted, fact about Afrikaans $\mathrm{NC}$ is that it is not always the case that both of the nies are actually realised in negative structures lacking specially designated n-words: there are cases where two nies systematically fail to occur despite the fact that a single negation reading of the sort illustrated in (1) is intended. Consider (2) and (3) by way of example. 
(2) Hy verstaan dit nog nie (*nie) he understand ${ }^{1}$ it still not not

"He still doesn't understand it"

\author{
a. Ek weet nie (*nie) \\ I know not not \\ "I don't know" \\ b. Ek weet NIE nie (nie) \\ I know not not not \\ "I don't not know", i.e., I do know
}

In (2), the second nie is obligatorily absent, meaning that just a single overtly realised negator is sufficient to produce a negative reading in this case. In (3), the situation is slightly different: as (3b) shows, a second or even a third nie is not impossible, but this necessarily results in a double negation reading of the kind that we find in non-NC languages; to obtain a single negation reading, just a single nie is required, as shown in (3a). In both (2) and (3), then, Afrikaans does not appear to be behaving in the manner that one would expect an $\mathrm{NC}$ language to do. The question that therefore arises is whether it is in fact correct to view Afrikaans as an NC language and, if the answer to this question is yes, how the presence vs. absence of the second or "agreeing" negator can be accounted for. These are the matters with which this paper is concerned.

The paper is structured as follows: section 2 presents the descriptive facts, while section 3 focuses on their analysis, and a conclusion is presented in section 4.

\title{
2. The Afrikaans negation facts
}

As noted in the introduction, it is generally accepted that Afrikaans is an NC rather than a Double Negation (DN) language like its closest (standard) Germanic relative, Dutch. ${ }^{2}$ The contrast between the two languages is clearly illustrated by the examples in (4) and (5). 
(4) a. Ik ben niet rijk

[Dutch]

I am not rich

"I am not rich"

b. Ek is nie ryk nie

[Afrikaans]

$\mathrm{I}$ is not rich not

"I am not rich"

(5) a. Zij hebben nooit een auto gehad

[Dutch]

they have never a car had

"They never had a car"

b. Hulle het nooit 'n kar gehad nie

[Afrikaans]

they have never a car had not

"They have never had a car"

As illustrated above, the negators in Afrikaans negative structures are identical in the absence of specific negators like nooit in (5b). These facts are well known, but what is less often noted in connection with Afrikaans negation is that negative structures do not always feature the "expected" number of negation elements. Consider (2-3) above and also the examples in (67).

(6) a. Ek verstaan nie

I understand not

"I don't understand"

a'. ... dat ek nie verstaan nie

b. Ek het nie verstaan nie

I have not understood not

"I didn't understand" 
b'. ... dat ek nie verstaan het nie that I not understood have not

"... that I didn't understand"

a. $\quad$ Ek ken nie min mense nie

I know not few people not

"I don't know few people" (i.e., I know a lot of people)

a'. $\quad$... dat ek nie min mense ken nie that I not few people know not

"... that I don't know few people"

b. Ek ken min mense nie

I know few people not

"There are few people I don't know"

b'. ...dat ek min mense nie ken nie that I few people not know not "... that there are few people I don't know"

Comparing (6a) and (6a'), we see that the simple-tense containing matrix clause features only a single nie, while two nies surface in the corresponding embedded clause. In the compoundtense counterparts of these structures (cf. $(6 b)$ and $\left.\left(6 b^{\prime}\right)\right)$, by contrast, two nies are required in both matrix and embedded contexts. In (7), we see a slightly different alternation. As comparison of (7a) and (7b) shows, the presence vs. absence of a second nie in this case correlates with an interpretive difference: where the second nie is present, negation outscopes the quantified object phrase $(\neg>$ few), but where it is absent, the reverse scope relations obtain $($ few $>\neg$ ). In the latter case, we therefore once again observe a circumstance under which a single nie produces a negative reading. As was the case for (6), two nies are, however, required in the embedded counterparts of both structures, and this requirement holds more generally of all embedded clauses: in contrast to matrix clauses, they must always contain two nies. The fact that native-speakers unerringly produce ( $\left.7 a^{\prime}\right)$ and ( $\left.7 b^{\prime}\right)$ when asked to give the embedded-clause counterparts of (7a) and (7b), respectively, strongly suggests that 
the objects in (7a) and (7b) are in fact located in different positions, with that in (7a) following the first nie as it clearly does in (7a'), while the object in (7b) precedes just as its counterpart in $\left(7 b^{\prime}\right)$ does. The same is true of the structures in (8).

\section{a. $\quad$ Ek ken nie daardie man nie}

I know not that man not

"I don't know that man (new information)"

a'. ... dat ek nie daardie man ken nie

that I not that man know not

"... that I don't know that man"

b. Ekken daardie man nie

I know that man not

"I don't know that man (old information)"

b'. ... dat ek daardie man nie ken nie

that I that man not know not

"... that I don't know that man"

In this case, the interpretive difference between the (a) and (b) examples is significantly more subtle than in (7), but the generalisation about structures of this type is that the object in (a)type structures tends to be interpreted as part of the information focus, either independently as new/focused information or as part of an all-rhematic structure of the kind that may serve to answer questions such as What happened?, while the object in (b)-type structures is necessarily interpreted as old information and, as such, structures of this kind are never felicitous as responses to thetic questions. More generally, inspection of matrix-clause pairs of the kind illustrated in (7) and (8) leads to the conclusion that objects in nie-doubling structures (cf. the (a) examples above) tend to differ interpretively from those apparently featuring nie-omission (cf. the (b) examples above) in roughly the manner that Diesing's (1992) Mapping Hypothesis would lead us to expect. In other words, nie-doubling vs. omission would seem to signal the presence vs. absence of scrambling in Afrikaans, a point to which we return in section 3.4 below. ${ }^{3}$ For the moment, however, our main concern is the fact 
that the data in (6-8) suggest that both semantic(-pragmatic) (i.e., scrambling vs. nonscrambling) and non-semantic factors (i.e., matrix vs. embedded clause-type, simple vs. compound tense) can play a role in conditioning the presence vs. absence of the two nies typically associated with Afrikaans NC.

It should be noted, though, that there are also structures in which "too few" nies are always mandatory where a single negation meaning is intended. Consider (9-10) in this connection.

a. Ekverstaan hom nie

I understand him not

"I don't understand him"

b. Ek verstaan waarskynlik/moontlik/sonder twyfel nie

I understand probably possibly without doubt not

"I probably/possibly/undoubtedly don't understand"

(10) a. Ek weet nie wat hy doen nie

I know not what he do not

"I don't know what he's doing"

a'. ... dat ek nie weet wat hy doen nie

b. Ek weet nie wat hy nie doen nie

I know not what he not do not

"I don't know what he doesn't do/isn't doing"

b'. ... dat ek nie weet wat hy nie doen nie

The examples in (9) illustrate two matrix contexts in which only a single nie is possible if a single negation reading is intended: matrix clauses featuring pronominal objects like (9a) are only compatible with a second nie where the intended meaning is "I don't not understand him", i.e., I do understand him, and the same is true of matrix clauses containing only an intransitive finite verb (cf. (3b) above) and of those in which this type of verb is modified by 
adverbials of the type illustrated in (9b). The examples in (10), in turn, show that structures like (10a) in which the matrix clause is negated exhibit the expected two nies, whereas those like (10b) in which both the matrix and the embedded clause are negated obligatorily feature only three. This state of affairs is replicated when this structure is further embedded within another clause, as shown in (10b').

Given the above data, the question that arises is whether Afrikaans is in fact a strict NC language in the sense of Giannakidou (2005). In other words, is it always the case that a semantically inert negation element must, in some sense, be co-present wherever "true" negators appear? I will argue that this is indeed the case; more specifically, I will argue that the presence vs. absence of the "second" nie in Afrikaans (henceforth: doubling vs. omission) is entirely predictable once one takes into account (i) the syntactic structure of negativecontaining sentences, and (ii) the way in which these are mapped onto phonological structure. As such, Afrikaans negatives are argued to facilitate specific insights into Afrikaans clause structure more generally, and also into how this compares to that of other Germanic languages and languages more generally.

\section{The analysis}

\subsection{Background}

Somewhat surprisingly given how frequently the distinctive negation pattern of Afrikaans is mentioned in the descriptive literature, it has not until recently received much attention in the generative literature (some early exceptions being Waher 1978, 1983, 1988; Den Besten 1986; Robbers 1992). In recent years, three distinct minimalist analyses have, however, emerged - Oosthuizen (1998), Molnárfi (2002, 2004), and Bell (2004a,b), all three of which focus on the nature and distribution of the "un-Germanic" clause-final negator of Afrikaans, the "second" nie (henceforth: nie 2 ). Biberauer (2006) evaluates these proposals, showing why a multiple-spellout proposal along the lines of Molnárfi's cannot be upheld and also highlighting various shortcomings of Bell's modified version of Oosthuizen's analysis. Here I will follow Biberauer (2006) in proposing an analysis of Afrikaans negation that also takes Oosthuizen (1998) as its starting point. 


\subsection{Distinguishing the two negators}

As is the case in other NC languages, the two negators in the NC structures of Afrikaans have very different functions: the first negator is the real or "true" negator (i.e., the contentful negation element), while the second (nie ${ }_{2}$ ) is most commonly viewed as a scope-marking element (i.e., a functional element; although see Biberauer (2006) and below for critical discussion of this view). This distinction also obtains when a negative structure contains two nies: the first $\left(\right.$ nie $\left._{1}\right)$ is the "true" negator, while the second is the "scope-marker". Crucially, therefore, Afrikaans differs from Romance-style NC systems in which the first element is the "true" negator, but the second is usually viewed as a reinforcer (contemporary spoken French being a well-known exception to this generalisation.). Synchronically, this would seem rather clearly not to be the case for $n_{2} e_{2}$, but see below (and also Roberge (2000) for a diachronic proposal that suggests an initially reinforcing origin for $n i e_{2}$, and Biberauer (2006) for further discussion of this point).

Let us consider the evidence in favour of treating the two nies in Afrikaans negative structures in the manner outlined above. Oosthuizen (1998) provides two compelling arguments. Firstly, he shows that (apparently) omitting the first negator always results either in ungrammaticality or a change in meaning. (nie $e_{2}$ is henceforth glossed NEG to reflect that fact that it does not contribute independent negative meaning to structures in which it occurs.)

(11) a. Hy kom nie in $_{\text {nie }_{2}}$

he come not in NEG

"He doesn't come in/He isn't coming in"

b. $\quad * H y$ kom in nie $_{2}$

he come in NEG

(12) a. Ek lees nie $_{1}$ sulke nonsens nie $_{2}$

I read not such nonsense NEG

"I don't read such nonsense"

[corresponding embedded clause: ... dat ek $\boldsymbol{n i e}_{1}$ sulke nonsens lees $\boldsymbol{n i}_{2}$ ] 
b. Ek lees sulke/SULKE nonsens ${ }^{*}$ nie $_{2} / \mathrm{NIE}_{1}{ }^{4}$

I read such nonsense not

"I emphatically do not read such nonsense!"

[corresponding embedded clause: ... dat ek sulke nonsens nie lees nie $_{2}$ ]

In (11), we see that omission of nie $e_{1}$ results in an ill-formed structure. The same is true if the first negator in (12a) is simply omitted, leaving only nie $e_{2}$ in clause-final position: Ek lees sulke boeke nie $_{2}$ is ungrammatical in exactly the same way (11b) is. Unlike with (11), however, there is in the case of (12) a grammatical structure featuring just a single clausefinal negator and that is the one in which the "real" negator, nie $e_{1}$, surfaces clause-finally. As shown in (12b), this structure is one which, unlike that in (12a), contains an object that has scrambled to the left of nie $e_{1}$. As noted in section 2, structures of this kind are interpretively distinct from those in which the object has not undergone scrambling. In this specific case, then, actually omitting nie $e_{1}$ results in ungrammaticality, whereas apparently omitting it (the scrambling case where the final negator is in fact nie $e_{1}$ ) results in a change in meaning. Further inspection reveals that this is generally true and that the correct generalisation about the omission of nie ${ }_{1}$ is in fact that it always results in ungrammaticality.

By contrast, omitting the second negator $\left(n i e_{2}\right)$ results in a structure that sounds like the final negator was mistakenly omitted (or as if the speaker is a non-native; native English speakers, for example, very commonly omit nie $e_{2}$. Thus the nie $e_{2}$-less counterparts of the above examples are interpreted precisely like their Standard Afrikaans (SA) counterparts in (11/12a) above, as in (13).

(13) a. Hykom nie in

he come not in

"He doesn't come in/He isn't coming in"

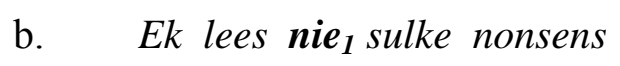

I read not such nonsense

"I don't read such nonsense" 
Oosthuizen also observes that only the first negation element can be modified, as in (14).

(14) a. Jy let glad/ hoegenaamd/absoluut/geheel en al nie ${ }_{1}$ op nie $_{2}$ you attend altogether/at-all/ absolutely/whole and all not up NEG "You aren't remotely paying attention"

b. $\quad *$ Jy let nie ${ }_{1}$ op glad/hoegenaamd/absoluut/geheel en al nie 2

Also notable in this regard is the existence of various lexicalised reinforced negatives (cf. (15)), all of which involve the first negator, as illustrated in (16).

(15) a. so nimmer as te nooit so never as to never "no way ever"

b. niks en niemand nothing and no-one

c. $\quad$ g'n niks no nothing "no nothing"

d. geen iemand no nobody "absolutely no-one"

e. geensins

no-sense

"not remotely"

f. geen stuk

no piece

"not at all" 
(16) a. Hy sal (so nimmer as te) nooit saamkom nie $_{2}$

He will so never as to never along-come NEG

"There's no way he'll ever come along"

b. Niks en niemand ${ }_{1}$ gaan hom daarvan oortuig nie $_{2}$ nothing and no-one go him there-of convince NEG

"Nothing will ever convince him of that"

Furthermore, it is only the first negator that can be reinforced by an "extra"/emphatic nie (cf. Zeijlstra's (2006) Emphatic Double Negation: crucially, to obtain this reading, the "true" negative element in such structures - cf. nooit in (17a) - must be stressed, while the following nie $\left(\right.$ nie $\left._{2}\right)$ is not).

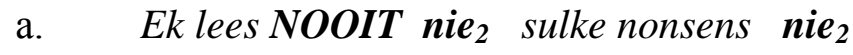

I read never not such nonsense NEG

"I NEVER read such nonsense"

$\left[\mathrm{SA}=\right.$ Ek lees nooit sulke nonsens nie $\left.{ }_{2}\right]$

b. *Ek lees nooit sulke nonsens nie nie $_{2}$

(18) a. Jy sal NêRENS nie so 'n wonderlike mens vind nie $_{2}$ you will nowhere not such a wonderful person find NEG "You just won't find such a wonderful person ANYWHERE" [SA = Jy sal nêrens so 'n wonderlike mens vind nie $\left._{2}\right]$

b. $\quad *$ Jy sal nêrens so ' $n$ wonderlike mens vind nie nie $_{2}$ nie

As it does not contribute independent negative meaning and is also omissible without resulting in either ungrammaticality or meaning-change, it is clear that the "extra"/reinforcing negator in these examples must be $n i e_{2} .{ }^{5}$ As hinted above, it is therefore not the case that the second negator in Afrikaans consistently fails to play a reinforcement role. 
A final observation about the relative "reinforceability" of nie $e_{1}$ and $n i e_{2}$ is that the first, but not the second nie, can be replaced with a more emphatic negator, both in formal (cf. (19)) and more colloquial (cf. (20-22)) registers; by contrast, the second nie cannot.

(19) a. Ons is nie $\boldsymbol{e}_{1}$ beïndruk nie 2

us is not impressed NEG

"We are not impressed"

b. Ons is geensins beïndruk nie

us is not-remotely impressed NEG

"We are not remotely impressed"

c. $\quad *$ Ons is nie $e_{1}$ beïndruk geensins

(20) a. Hy het nie 1 geld nie

he have not money NEG

"He doesn't have any money"

b. Hyhet niks geld nie $_{2}{ }^{6}$

he have nothing money NEG

"He doesn't have any money"

c. $\quad * H y$ het nie ${ }_{1}$ geld niks

(21) a. Hy is nie 1 'n goeie mens nie he is not a good person NEG

"He isn't a good/nice person"

b. Hy is g'n 'n goeie mens nie

he is none a good person NEG

"He is not a good person"

c. *Hy is nie ${ }_{1}$ 'n goeie mens g'n 
(22) a. Hy wil nie $_{1}$ luister nie 2

he will not listen NEG

"He won't listen"

b. Hywil g'n niks luister nie 2

he will none nothing listen NEG

"He won't listen at all"

c. $\quad *$ Hy wil nie ${ }_{1}$ luister g'n niks

Two further pieces of evidence distinguishing the two nies draw on parallels which these elements respectively do and don't show with the strong and weak elements discussed in Cardinaletti and Starke (1996): while the first negator can be co-ordinated, the second cannot, as shown in (23), and while the first negator can be stressed, the second cannot, as (24) shows.

(23) a. Eksal niks en niemand hiermee vertrou nie ${ }_{2}$

I will nothing and no-one here-with trust NEG

"I won't trust a soul with this"

b. $\quad *$ Ek sal niks hiermee vertrou nie en $_{2}$ niemand

(24) a. Ek weet NOOIT/NIE 1 wat hy doen nie 2

I know never not what he do NEG

"I NEVER know what he's doing/I DON'T know what he's doing/he does"

b. $\quad *$ Ek weet nooit/nie $e_{1}$ wat hy doen $\mathrm{NIE}_{2}$

Taken together, the evidence discussed here therefore points to an analysis in terms of which the two nies are fundamentally very different (contra Molnárfi 2002, 2004). 


\section{3 $\mathrm{Nie}_{1}$ is a Neg-head and $\mathrm{Nie}_{2}$ is a (CP-related) Polarity-head}

Oosthuizen proposes capturing the difference between the two elements by assigning nie $_{1}$ the status of a Neg-head, which is merged relatively low in the clause, while viewing nie $_{2}$ as a Pol(arity)-head, which is merged at the clause-edge, above CP (cf. Laka $(1990,1994)$ for the proposal that PolP may surface either above or below IP, subject to parametric variation, and Biberauer (2006) for discussion of the validity of assuming a CP-related PolP for Afrikaans). I will adopt this proposal here, with minor modifications, the motivations for which are elaborated in Biberauer (2006). The modifications are as follows: where Oosthuizen postulates a NegP just above AgrOP to host $n_{i e}{ }_{1}$, I assume that there is no need to postulate a distinct NegP and that nie ${ }_{1}$ in fact adjoins to the outer edge of VP (although see below for further discussion).

To see how the proposed analysis works, consider the example in (25) (strikethrough indicates a lower copy that is not spelled out).

a. $\quad$ Ek kan sien [dat jy hoegenaamd nie verstaan $_{\mathbf{n i}}$ ]

I can see that you totally not understand NEG

"I can see that you don't understand at all"

b. PolP

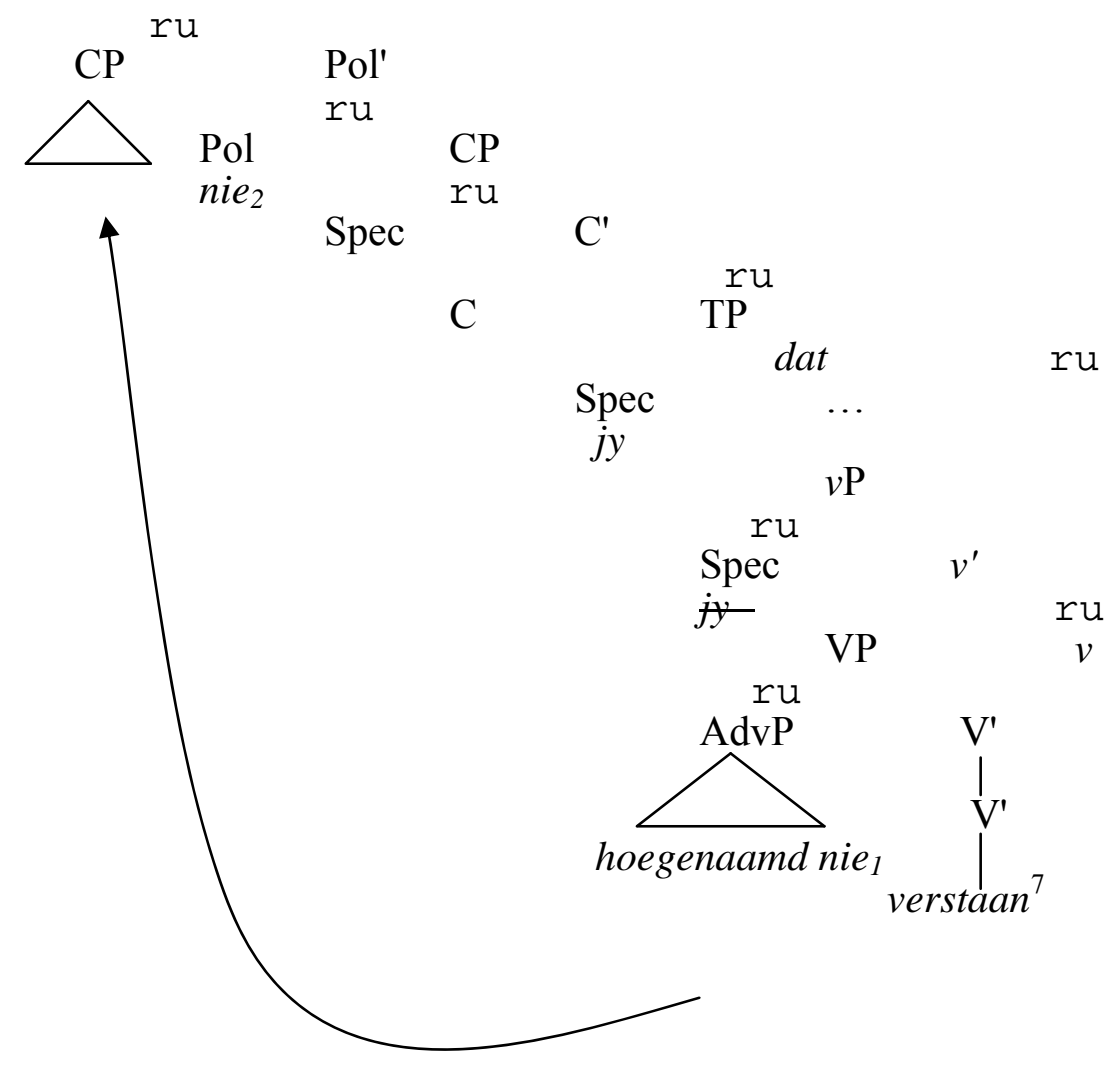


Here (25b) illustrates just the embedded structure indicated in square brackets in (25a). For expository purposes, I abstract away from various details of Afrikaans clausal structure. The noteworthy aspects of the structure are as follows:

(i) the "true" negator - nie $e_{1}$ modified by the intensifier hoegenaamd - is a low adjunct to $v \mathrm{P}$, which I have labelled $A d v P$ to reflect the fact that I view negation phrases as a species of adverbial with no special status (cf. also Zeijlstra (2004) for Germanic more generally). ${ }^{8}$ They therefore adjoin, just like other adverbials, at specific adjunction points along the "main spine" of the clause. Empirical evidence (discussed in more detail in Biberauer (2006)) suggests that this adjunction point is low, but nevertheless higher than the merge position of both internal arguments; ${ }^{9}$ hence the assumption, for the moment, that the negative adverbial is adjoined to the outer edge of VP. I will return to this point in section 3.4 below (see also Note 16).

(ii) $\quad n i e_{2}$ is a polarity-head merged above CP. Following Oosthuizen (1998), I assume that Afrikaans negated clauses are headed by a Polarity Phrase (PolP) which specifies the polarity of the clause in question as negative. ${ }^{10} \mathrm{I}$ adopt the ProbeGoal system of Chomsky (2000 et seq.) in terms of which this Pol-head bears an unvalued pol-feature $\left(\left[\mathrm{Pol}: \_\right]\right)$and therefore acts as a probe for valued [pol]features (e.g. [Pol: neg]) in its c-command domain, establishing an Agree relationship with them. I also assume that Pol is associated with an EPP-feature (Move diacritic), which requires movement of the goal-containing category to its specifier. Although the goal in this case is arguably the negative adverbial, hoegenaamd nie ${ }_{1}$, the entire $\mathrm{CP}$ undergoes raising to Spec-PolP, i.e., Pol's EPPfeature is satisfied by clausal pied-piping of the kind that has also been proposed for a range of other left-periphery-related domains. ${ }^{11}$

This proposal would seem to have numerous advantages. Firstly, the proposed analysis allows Afrikaans to be viewed as a language whose negation/polarity behaviour emerges as rather similar to that which has been identified in other natural languages (cf. Laka 1990, 1994; Holmberg 2001, 2005; Ouali 2003, 2005, 2006; Déchaine and Wiltschko 2003; Munaro and Poletto 2004; Kandybowicz 2006; Vicente 2006), always a desirable result in the generative context. Secondly, the proposed analysis also seems to make sense when viewed from the 
perspective of the specific diachronic circumstances that led to the rise of this structure in Afrikaans: as argued in Biberauer (2006), there seem to be very good reasons for viewing $n i e_{2}$ as an element that originally served primarily a discourse function, i.e., one that naturally belongs in the CP-domain (cf. Roberge (2000) for detailed discussion of nie ${ }_{2}$ 's origins as a discourse-level element, specifically one expressing "resumptive negation"). Focusing more specifically on individual aspects of the structure of Afrikaans negation, the proposed analysis also facilitates a simple explanation of nie 2 's lack of modifiability and "emphaticization": since the head which is ultimately spelled out as nie 2 is an EPP-bearing probe, its specifier needs to be filled by the goal-bearing XP it attracts, not by a non-selected modifying element. Similarly, nie $e_{2}$ 's unstressability arguably falls out from the fact that $n i e_{2}$ will never be located in a position to which phrasal, much less sentential stress can be assigned: it will never be the most deeply embedded element (cf. Cinque 1991; Zubizaretta 1998), nor will it ever be at the relevant "edge" of edge-alignment-based accounts of stress assignment (cf. Selkirk 1995; Truckenbrodt 1995; and see also below) nor can it ever be at the left edge of a "spellee" (i.e., the constituent sent to Spellout upon completion of a phase) in theories that assume this to be the crucial stress-determining configuration (cf. Kahnemuyipour 2005). Finally, two less frequently mentioned, but nevertheless otherwise puzzling facts about nie ${ }_{2}$ 's distribution fall out straightforwardly if we view this element as a polarity marker: firstly, the fact that it is not, contra the quite widespread view that it constitutes a scope-marking element, consistently the element signalling scope-marking facts. Consider (26) in this connection.

a. Hysê nie $_{1}$ dat hy kom $\mathbf{n i e}_{2}$ he say not that he come NEG

"He isn't saying that he is coming"

b. Hysê dat hy nie $\boldsymbol{i}_{1} \mathrm{kom} \mathbf{n i e}_{2}$

he say that he not come NEG

"He says that he isn't coming"

In (26), nie $_{2}$ consistently surfaces clause-finally, with nie ${ }_{1}$ appearing to determine the scope of negation. On the polarity view of $n e_{2}$ 's function, this state of affairs emerges as unsurprising (as do the cases in which nie 2 does appear to serve as a scope-marker - cf. Biberauer (2006) for further discussion). The second otherwise puzzling aspect of nie $e_{2}$ 's distribution (originally 
noted by Oosthuizen 1998: 79) that receives an explanation under the analysis outlined here is that this element is, in colloquial usage, permitted to surface in structures lacking a negator. Consider (27) in this connection.

a. $\quad$ Ek kan my nouliks/skaars inhou $\mathbf{n i e}_{2}$

I can me barely in-hold NEG

"I can barely contain myself", i.e., I'm very excited

b. Ekweier om saam te kom nie $_{2}$

I refuse $\mathrm{C}$-INF together to come NEG

"I refuse to come along"

If nie $_{2}$ were simply a scope-marking negation element, dependent on a "true" negator, the data in (27) would be mysterious. On the view that $n^{2} e_{2}$ is in fact a polarity element, this mystery, however, disappears: investigation of structures which permit the realisation of $n_{i} e_{2}$ in the absence of a "true" negator reveals that the element they necessarily feature is one belonging to the class of (non)veridical operators, i.e., the class that Giannakidou (1999 et seq.) identifies as necessary to license a polarity item. $\mathrm{Nie}_{2}$ is therefore possible in (27a) thanks to the presence of the approximative adverb, nouliks (cf. Horn (2002) for recent discussion), while factive weier in (27b) is a negative one-way implicative (cf. Kiparsky and Kiparsky (1971) and also Nairn, Condoravdi and Karttunen (2006) for recent discussion). That these elements are indeed the crucial licensers as far as nie $e_{2}$ is concerned is clearly shown by the minimally different structures in (28), each of which replace the putative licenser with an element not associated with (non)veridicality.

(28) a. Ek kan my (maklik) inhou $\left({ }^{*}\right.$ nie $\left._{2}\right)$

I can me easily in-hold NEG

"I can contain myself"

b. Ek onderneem om saam te kom (*nie ( $_{2}$

I under-take $\mathrm{C}$-INF together to come NEG

"I undertake to come along" 
In sum, then, a wide range of data appear to corroborate the analysis of nie $e_{1}$ and $n i e_{2}$ proposed here.

One specifically nie $e_{2}$-related question that we have not addressed so far, but that undoubtedly deserves special attention in view of the availability of a superficially simpler analysis, relates to the analysis of $n_{i} e_{2}$ as the head of a head-initial PolP in the CP-domain. As argued above, there appears to be strong evidence in favour of the view that PolP in Afrikaans is CP-related; what has not been shown, however, is that this PolP needs to be head-initial - can it not simply be head-final, thereby precluding the need for clausal pied-piping? Leaving aside the loss of the parallels with other "clausal pied-piping" languages mentioned above, there are at least two considerations that suggest that the answer is no.

The first of these is primarily theoretical. CP is clearly head-initial in Afrikaans (and Germanic generally) - cf. the various examples in this paper of clauses featuring an overt complementiser. If $n i e_{2}$ is, as argued above, located within the head-initial CP-domain, it is not obvious how PolP could be head-final: to my knowledge, there is no language in which there is variation in respect of the headedness of projections within "articulated" CPs; if PolP in Afrikaans is in fact head-final, this is, however, precisely the assumption that would have to be made for Afrikaans.

The second relevant consideration, an empirical one, would seem to argue even more strongly in favour of the rejection of a head-final PolP: as noted by Oosthuizen (1998) and illustrated in (29) below, it is possible for elements to "leak" past nie ${ }_{2}$.

(29) a. Sy het tydens die vergadering niks gesê nie she have during the meeting nothing said not "She said nothing during the meeting"

b. Sy het niks gesê nie 2 tydens die vergadering she has nothing said NEG during the meeting

On the view that PolP is both CP-related and head-final, structures like the (b)-structures in (29) should not be possible as nie 2 should always surface clause-finally. As noted in 
Biberauer (2006), a restricted (and poorly understood) range of structures of this type is, however, attested in spoken Afrikaans. Ignoring the evidence pointing to the CP-relatedness of Afrikaans PolP highlighted above and postulating - as, for example, Bell (2004a,b) has done - that PolP is in fact a clause-internal projection located lower down in the clausal architecture also will not "rescue" the head-final view on nie $e_{2}$ : the fact that "low" adverbials like the locative PP in (29b) may surface post-nie $e_{2}$ indicates very clearly that even a maximally lowly adjoined head-final PolP will not be able to account for the "leaking" data (and, clearly, such an analysis would also pose rather serious problems for the manner in which nie $e_{2}$ is interpreted: it is very evidently not generally associated solely with the contents of VP). By contrast, a head-initial, clausal pied-piping proposal of the kind advocated here has open to it the possibility that certain elements may be "stranded" when pied-piping takes place (cf. what we see in the context of wh PP-fronting). I leave the details of this type of analysis for future research, but cf. Biberauer (2003) and Biberauer and Roberts (2005) for discussion of how "leaking" phenomena might be accounted for in a phase-based framework. For present purposes, it seems fair to conclude that the proposal that $n i e_{2}$ may in fact head a head-final PolP seems to face both empirical and theoretical problems. We will therefore proceed on the basis of the assumptions outlined in this section.

Let us now consider how these enable us to account for the doubling and omission structures that surface in negation contexts.

\subsection{Accounting for the alternation of doubling and omission structures}

The starting point for our analysis is that also assumed by Den Besten (1986), Robbers (1992), and Bell (2004a,b), namely that $n_{i} e_{2}$ is always syntactically present in every negation structure. In other words, Afrikaans is indeed a strict negative concord language. If this is correct, the fact that not every Afrikaans sentence contains two negation elements has to be understood as the consequence of some kind of deletion operation. Clearly, then, the question is what kind of operation this is.

Robbers (1992) is sometimes incorrectly cited as having proposed that a so-called Doubly Filled NegP Filter along the lines given in (30) is responsible for the distribution of Afrikaans negation elements (where in fact, (30) represents an attempt to capture the distribution of Italian non). 
(30) Doubly Filled NegP Filter

*[NegP $\mathrm{n}$-word [Neg $\mathrm{n}$-marker] [T ....]]

According to (30), structures with two adjacent negators should not be possible, a state of affairs which clearly does not hold in Afrikaans, as i.a. the possibility of emphatic negation structures such as those illustrated in (17-18) above and also structures such as those in (31) clearly show (semantics aside, the stressability difference between the nies in the (a) and (b) examples clearly show that (b) features "true" negator nie ${ }_{1}$, while (a) contains polaritymarking nie $_{2}$ ).

(31) a. Ek ken niemand nie $2 / * \mathrm{NIE}_{2}$

I know no-one NEG

"I don't know anyone"

b. Ek ken niemand *nie ${ }_{1} /$ NIE $_{1}$

I know no-one not

"There is no-one I don't know"

The Doubly Filled Neg Filter in (30) cannot therefore account for the facts at issue here, as negators may surface adjacent to one another in Afrikaans. According to Den Besten (1986: 202), the relevant filter in fact takes the form given in (32).

$$
\text { * nie nie }
$$

In terms of (32), it is therefore specifically two nies that cannot surface adjacent to one another. Closer investigation, against the background of what we have established in sections 3.1 and 3.2 about the nature of the two nies of Afrikaans, reveals that nie 2 is the "missing" nie in each case: consider, for example, the fact that the absence of the relevant nie does not affect the negative semantics of the resulting structure, and also the fact that the nie that is present can be strengthened in the various ways discussed in section 3.2 This is illustrated for (6a), repeated here as (33a). 
a. Ek verstaan NIE

I understand not

"I DON'T understand"

b. Ekverstaan hoegenaamd nie

I understand totally not

"I don't remotely understand"

c. Ekverstaan geensins $\left(\right.$ nie $\left._{2}\right) / * N I E_{2}$

I understand no-sense NEG

"I don't remotely understand"

As shown above, it is possible to stress the single nie in (6a) (cf. (33a)), it is possible to modify it (cf. (33b)) and it is also possible to replace this nie with a stronger negative (cf. geensins in (33c)). That nie ${ }_{1}$ has in fact been replaced by geensins in this last example and that the nie that surfaces in this structure is $n i e_{2}$ is clearly shown by the fact that (i) it cannot be stressed, and (ii) it can, colloquially, be omitted without resulting in an ungrammatical or non-negative sentence; the resulting structure will simply be viewed as "missing something" in the same manner as nie $e_{2}$ lacking ones discussed in section 3.2 above (cf. (13)). ${ }^{12}$

Having established that it is in fact nie 2 which is missing in omission structures, let us attempt to refine Den Besten's (1986) filter proposal so that we can test whether it will enable us to account for the doubling and omission structures in Afrikaans. Consider the haplology mechanism in (34). ${ }^{13}$

$$
\begin{aligned}
& \text { Afrikaans Syntactic Haplology mechanism (Take 1) } \\
& \mathrm{Nie}_{2} \text { is subject to PF deletion whenever it is sent to Spellout in a position where it } \\
& \text { will end up (following copy deletion) being the element which is spelled out } \\
& \text { immediately adjacent to a nie } \\
& \text { i.e., ... nie nie } \text { n }_{2} \rightarrow \text { nie nie }
\end{aligned}
$$

What (34) predicts is that nie $_{2}$ will be deleted wherever raising to Spec-PolP (under the influence of Pol's EPP-feature) involves raising an XP of which the rightmost ultimately 
spelled-out element is a nie; conversely, nie $_{2}$ will be spelled out wherever the rightmost ultimately spelled-out element is something other than a nie. This is schematically illustrated in $(35)$.

a.

PolP

ru Spec

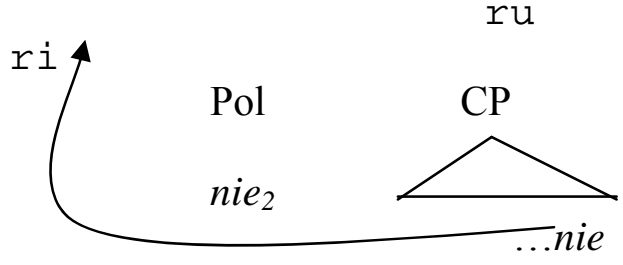

$\rightarrow$ nie $_{2}$ deleted b.

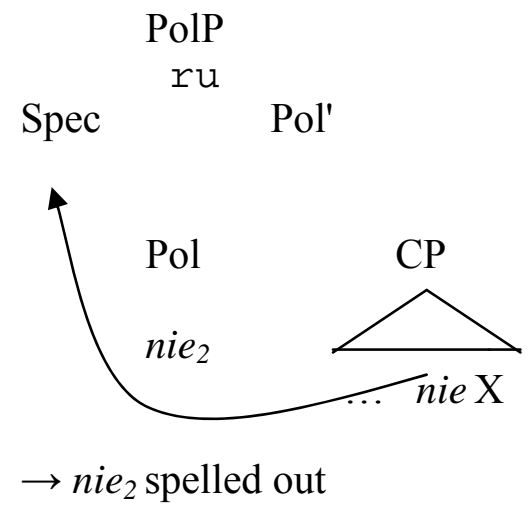

Let us investigate how this proposal fares in accounting for the doubling and omission structures presented thus far. Consider, firstly, a structure in which nie 2 systematically fails to surface, unmodified intransitive verb-featuring (6a)/(33), just discussed. (34) predicts that nie ${ }_{2}$ will undergo OCP-style deletion whenever it ends up being spelled out adjacent to a nie (only the first of two phonologically identical elements survives OCP-induced deletion (cf. Leben 1973). Inspection of the (partial) structure in (36) reveals that this is indeed the configuration underlying (6a)/(33). (strikethrough once again indicates copy-material that is suppressed under Chain Reduction. Obviously, the CP-complement of nie 2 is also deleted as the CP is spelled out in its moved position; for presentational reasons, strikethrough has, however, not been employed in this case.)

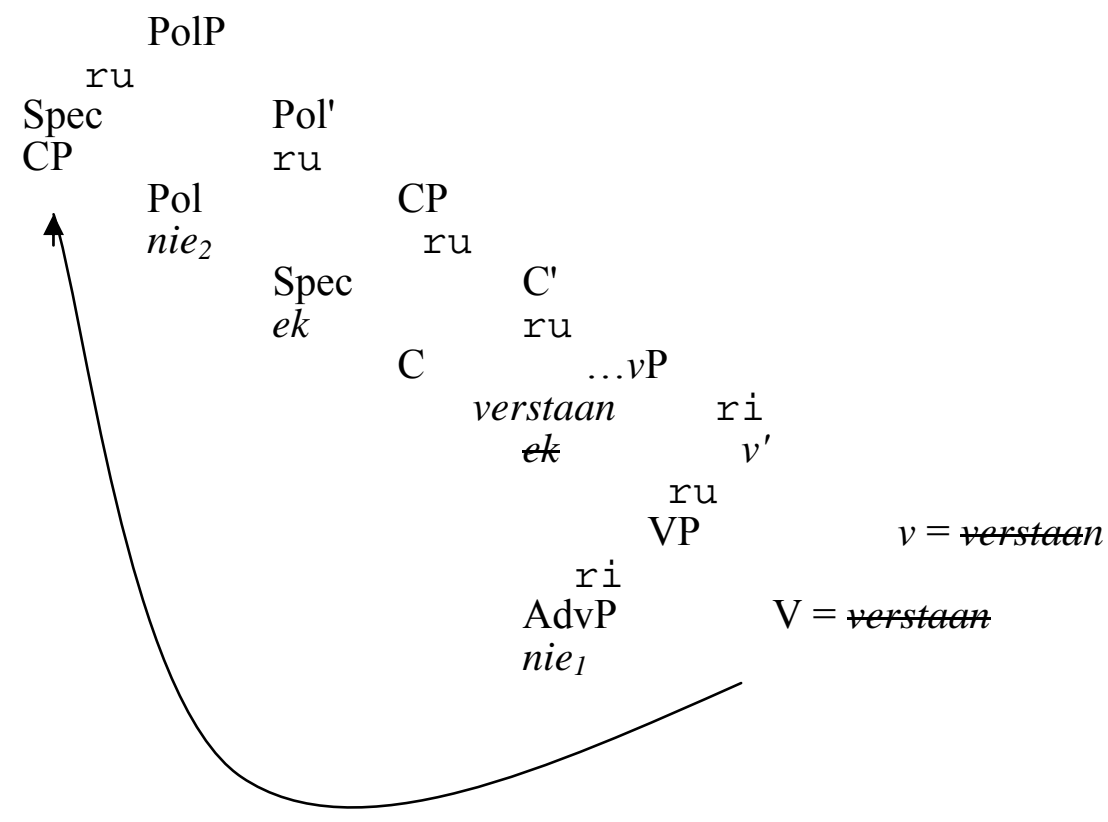


On standard assumptions about the structure of West Germanic V2 clauses (cf. Den Besten 1977/1983) which are also well motivated for Afrikaans (cf. Biberauer 2003), verstaan undergoes raising to $\mathrm{C}$. At $\mathrm{PF}$, it will therefore be spelled out in this position, with lower copies (in $\mathrm{T}, v$, and $\mathrm{V}$ ) being suppressed/deleted in accordance with some chain reduction mechanism (cf. Nunes (2004) on the operation Chain Reduction). Crucially, suppression of the copy of verstaan in $\mathrm{V}$ means that the rightmost overtly realised element in the $\mathrm{CP}$ which underwent raising to Spec-PolP will be nie $e_{1}$, i.e., it creates the environment in which (34) will apply. The non-occurrence of nie $_{2}$ in structures like (6a)/(33) is therefore accounted for.

Contrast the embedded and compound-tense counterparts of (6a)/(33) given in (37).

a.

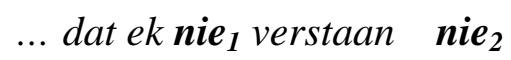
$\left(=\left(6 a^{\prime}\right)\right.$ above $)$ that I not understand NEG "... that I don't understand"

b. Ek het nie $_{1}$ verstaan nie $_{2}$ $(=(6 b)$ above $)$

I have not understood NEG

"I didn't understand"

In both of these cases, both nies are overtly realised. This follows straightforwardly from (34) if we take into account the fact that both of these structures feature a verb (verstaan) which is standardly thought to remain in V (cf. Vikner (2005) for recent convincing argumentation that West Germanic verbs do not undergo raising in non-V2 contexts): verstaan is therefore the rightmost ultimately spelled-out element in the CP that raises to Spec-PolP, with the result that $n i e_{1}$ and $n i e_{2}$ do not end up in the OCP configuration, allowing both to survive. ${ }^{14}$ More generally, (34) predicts that all structures in which the lexical verb has remained in situ - thus, all non-V2 embedded clauses and compound-tense structures - will consistently feature two negators. This prediction is correct, as inspection of all the relevant types of examples in this paper will reveal (cf. also Donaldson (1993) for an overview of doubling structures in Afrikaans).

Furthermore, (34) also predicts that structures in which the VP contains overtly realised material will feature two negators. We would therefore expect transitive structures to contain 


\section{Theresa Biberauer}

two nies. Investigation of i.a. the examples in (2) and (7b) above, however, reveals that this is not always the case: only one nie is realised in structures featuring pronominal objects (cf. (9a)) and the same is true for those featuring full DPs which receive some kind of "old information" interpretation (cf. i.a. (8b)). Significantly, as noted above, these very structures are the ones typically analysed as involving either defocusing scrambling movement out of the VP (cf. i.a. Diesing 1992) or base-generation above VP-adverbials (cf. i.a. Neeleman and Weerman 1999). Regardless of which of these analyses is correct, it is clear that they both entail the assumption that "old information" transitives differ from their "new information" counterparts in respect of the positioning of the object: whereas "new information" objects are VP-internal, their "old information" counterparts are VP-external. That nie 2 should be present in the former, but not the latter case therefore falls out straightforwardly from (34): it is only in the "new information" case (where the object is VP-external) that the object will intervene between nie $_{1}$ and nie $_{2}$, thereby allowing both to be pronounced. ${ }^{15}$

So-called VP-adverbs represent another type of material that (34) leads us to expect to play a role in determining the presence vs. absence of $n_{i} e_{2}$ in simple-tense intransitive matrix clauses (non-V2 embedded and compound-tense clauses always feature two nies for the reasons given above, and non-intransitives will feature two nies wherever the VP contains material over and above nie $)_{1}$ : if it is indeed the case that "true" negators are, as we have been assuming, adjoined at the outer VP-edge, we would expect other VP-adverbs, i.e., elements which are also traditionally assumed to be adjoined to the VP-edge, to be able to intervene between nie $e_{1}$ and nie $_{2}$, thereby ensuring that both nies are produced. ${ }^{16}$ This is indeed the case, as illustrated in $(38)$.

a. Ekverstaan nie $_{1}$ altyd/ maklik/gou $\mathbf{n i e}_{2}$

I understand not always/easily/ quickly NEG

"I don't always understand/I don't always understand easily/quickly"

b.

\begin{tabular}{|c|c|c|}
\hline \multicolumn{3}{|c|}{ VP } \\
\hline$r u$ & & \\
\hline AdvP & $\mathrm{V}^{\prime}$ & \\
\hline nie $_{1}$ & $\mathrm{AdvP}^{r i}$ & $\mathrm{~V}=$ verstaan \\
\hline
\end{tabular}


As the relative ordering of the adverbials in (38a) indicates, it is possible for VP-adverbs to follow nie ${ }_{1}$. If we assume the usual adjunction site for these adverbs to be the edge of VP, it becomes possible to account for the presence of two nies in the structures concerned: under those circumstances, these VP-adverbs will be spelled out to the right of nie ${ }_{1}$, with the consequence that (34) cannot apply. Significantly, however, VP-adverbs do not always surface in structures featuring two nies - cf. (39).

a. Ek verstaan altyd/ maklik/gou nie

I understand always/ easily/ quickly not

"I always/easily/quickly don't understand"

b.
AdvP
altyd/maklik/gou $\underset{\text { AdvP }}{\mathrm{ru}} \mathrm{V}^{\prime}$

As (39) shows, VP-adverbials may also precede $n i_{1}$. Crucially, however, the relative scope relations between the negator and the adverbs are reversed in this case (cf. parallel differences which emerge in the context of quantified object-containing structures such as (7) above). I take this as evidence that "true" negators and VP-adverbs belong to the same general adverb domain, within which they may adjoin freely (contra Cinque 1999). If nie ${ }_{1}$ is indeed merged "low", one would expect it (i) consistently to follow "higher" adverbs, both those usually assumed to be associated with the TP-domain and those generally thought of as CP-related, and (ii) to surface in isolation in contexts where "higher" adverbs surface in the absence of overtly realised VP-internal material. These expectations are borne out, as illustrated in (40).

(40) a. Ekverstaan eerlikwaar/waarskynlik/moontlik nie $_{1}$

I understand honestly/ probably/ possibly not

"I honestly/probably/possibly don't understand"

b. $\quad$ Ek verstaan $\boldsymbol{n i e}_{1}$ eerlikwaar/waarskynlik/moontlik $\boldsymbol{n i e}_{2}$ 
Taken together, the adverb data therefore support the proposal that nie $e_{2}$-deletion is conditioned by an "exposed" left-edge of VP, i.e., one where nie $e_{1}$ ends up being the rightmost spelled-out element.

Fronting structures represent a further context in which nie $e_{1}$ may be "exposed" in this manner. Consider (41-42) in this connection.

(41) a. Hy lees nie $_{1}$ die Telegraph nie $_{2}$ he read not the Telegraph NEG "He doesn't read the Telegraph"

b. Die Telegraph lees hy nie the Telegraph read he not "The Telegraph, he doesn't read"

(42) a. Wie lees nie $\boldsymbol{n}_{1}$ die Telegraph nie $_{2}$ ? who read not the Telegraph NEG "Who doesn't read the Telegraph?"

b. Wat lees Jan nie $\boldsymbol{n}_{1}$ ? what read John not

"What doesn't John read?"

c. Waarom verstaan jy nie $\boldsymbol{e}_{\mathbf{1}}$ ?

why understand you not

"Why don't you understand?"

In (41a), we see the now familiar "new information" structure featuring a VP-internal object, which therefore precludes the application of (34). By contrast, the object-fronting structure in (41b) behaves exactly like the scrambling structure, with movement of the object out of the VP resulting in nie $_{1}$ being "exposed" at the right edge of the constituent (CP) which raises to Spec-PolP; nie $_{2}$ is therefore deleted. In (42a), we see that fronting of a wh-subject does not result in nie $_{2}$-deletion when VP-internal material is present, as expected. By contrast, fronting 
of a wh-element that would otherwise have constituted the only material internal to VP does trigger nie $_{2}$-deletion, once again as expected. ${ }^{17}$ In sum, then, (34) would seem to be able to account for the doubling and omission patterns presented in section 2 , in which only a single semantic negation is involved. This leaves the multiple negation structures in (10) to be accounted for. The relevant data are repeated here as (43).

a. Ek weet nie wat hy doen nie

I know not what he do not

"I don't know what he's doing"

a'. ... dat ek nie weet wat hy doen nie

b. Ek weet nie wat hy nie doen nie

I know not what he not do not

"I don't know what he doesn't do/isn't doing"

b'. ... dat ek nie weet wat hy nie doen nie

As (43b) shows, structures involving two negated clauses differ from those in which just one clause is negated in that they systematically lack the expected number of negators. Furthermore, this discrepancy is not "remedied" in embedded contexts as was consistently shown to be the case in single negation-containing structures - contrast $\left(43 b^{\prime}\right)$ with the examples in (6-8), for example. The question is why this should be.

Note, firstly, that doubling is obligatory in structures featuring clausal complements (cf. $\left.\left(43 a / a^{\prime}\right)\right)$. This indicates that these complements cannot have raised from their base-position as is sometimes assumed: if raising had occurred, nie ${ }_{1}$ would have been "exposed" at the edge of VP in (43a), with the result that it would have been spelled out adjacent to nie ${ }_{2}$, thereby creating the deletion environment specified in (34). With this much in place, we can begin to understand why multiple negation structures like (43b/b') only contain three nies: in this case, we are in fact dealing with two PolPs as schematised in (44).

(44) $\left[\mathrm{PolP}[\mathrm{CP}\right.$ Ek weet nie 1 [PolP [CP wat hy nie 1 doen $]$ nie $\left._{2}\right]$ nie $\left._{2}\right]$ 
As shown in (44), the verb in multiple negation structures like (43b/b') takes a PolPcomplement which is structured in the usual way, i.e., it consists of a $\mathrm{CP}$ which has undergone movement to Spec-PolP under the influence of Pol's EPP-feature. The matrix clause is, however, also a PolP, with the consequence that the entire matrix $\mathrm{CP}$, including the PolPcomplement selected by the matrix verb, undergoes raising to the specifier of matrix PolP. This, then, creates a scenario in which two nies are ultimately spelled out adjacent to one another. (34) therefore applies, with the result that the second of these nies - matrix $n_{i} e_{2}$ - is deleted. To sum up, then, (34), in combination with independently motivated assumptions about the "West Germanic" nature of Afrikaans clause structure would appear to make the correct predictions vis-à-vis the presence vs. absence of nie-doubling in all of the structures considered so far.

The question that now arises is whether (34) can in fact account for all doubling and omission phenomena in Afrikaans. As examples like (45) show, this is not the case.

a. Hy sing nie n $_{1}$

he sing not

"He doesn't sing"

b. Hy sing nie $_{1}\left({ }^{*}\right.$ nie 2$)$

he sing not NEG

c. Hy sing NIE $_{1}$ nie $_{1}$

he sing not not

"He doesn't not sing", i.e., He does sing

As (45c) reveals, it is not impossible for two nies to surface adjacent to one another: two nies can co-occur if they are both "true" negators. At first sight, this might seem to follow straightforwardly from (34), which states that nie $e_{2}$ is deleted whenever nie $e_{1}$ is spelled out adjacent to it; (34) does not specify that the second of two adjacent nie $e_{1}$ s should also undergo deletion. What needs to be remembered, though, is that (34) applies at the stage where the feature-bundles operated on by Narrow Syntax have been converted into phonological form, i.e., OCP-style deletion takes place after the Vocabulary Insertion stage assumed by 
Distributed Morphologists (cf. Halle and Marantz 1993 et seq.). At the stage at which (34) applies, it will therefore no longer be possible to distinguish nie ${ }_{1}$ and nie $e_{2}$ on the basis of their distinct featural make-up as they will simply be lexical items with identical segmental characteristics. How, then, can PF determine when adjacent nies are admissible and when they are not?

One possibility suggested by consideration of the examples in (45) might be that stress differences provide the crucial distinguishing factor: the adjacent $n i e_{1} \mathrm{~s}$ in $(45 \mathrm{c})$ are evidently non-identical in stress profile, whereas the proscribed nie $e_{1}-n i e_{2}$ structure in (45b) arguably features two nies that are at least potentially indistinguishable on stress or other grounds. If (34) takes place following sentence-level stress assignment (i.e., relatively late in the PF process, see below), we might be able to account for the discrepancy in (45). That this is not the crucial consideration is, however, clearly shown by two independent empirical facts. Firstly, stressing nie $e_{1}$ in (45b) (i.e., *Hy sing $N I E_{1}{ }^{*}{ }^{2} e_{2}$ ) does not result in a grammatical structure; it simply results in a string which, if it is to be viewed as grammatical, must be interpreted like (45c), i.e., as one featuring two "real" negators. Secondly, structures such as those in (46) also clearly show that adjacent nies are permitted even where stress does not serve a distinguishing function.

a. Ekwil mense wat nie omgee nie $_{2}$ nie $_{1}$ sien nie $_{2}{ }^{18}$

I want people who not care NEG not see NEG

"I don't want to see people who don't care"

b. Ek sien nie die tweede 'nie $_{1}$ ' nie $_{2}$

I see not the second nie NEG

"I don't see the second nie"

In (46a), we see a nie -nie $_{1}$ sequence being spelled out despite the absence of a stress difference, while (46b) shows that the reverse, i.e., the ordering proscribed by (34), is also possible. That adjacent $n_{i} e_{1}-n i e_{2}$ is not systematically ruled out is also very clearly shown by the following example, which shows that not just two, but three nies may be spelled out adjacent to one another. 


\author{
Hy sing NIE $_{1}$ nie $_{1}$ nie $_{2}$ \\ he sing not not NEG \\ "He doesn't not sing"
}

This structure in fact represents the standardly correct counterpart of (45c), the latter structure being one that is most commonly heard in spoken Afrikaans, particularly, but not exclusively, that produced by non-natives - in other words, $(45 \mathrm{c})$ represents the same kind of structure as the $n i e_{2}$-lacking structures discussed in section 3.2. ${ }^{19}$ For present purposes, the crucial point is that these structures differ from superficially very similar nie $e_{1}$-nie $e_{2}$-containing ones like (45b) above in that they, unlike (45b)-type structures, represent structures sanctioned by PF: whereas the deletion algorithm in (34) automatically deletes the second nie in (45b)-type structures, it does not do so whenever a structure contains adjacent nie $e_{1} \mathrm{~s}$ as is the case in (45c). And (47) shows that three adjacent nies are also permitted.

Clearly, therefore, (34) will need to be refined in order to capture the empirical facts. Specifically, it will need to be refined in such a way that PF will be able to "see" the difference between nies requiring deletion and those which must survive. What the discussion above has shown is that the deleted nie is always nie 2 (recall that "missing" nies do not result in the loss of negated meaning). What we therefore need to understand is how PF can identify a nie $_{2}$ requiring deletion, without actually being able to distinguish $n i e_{1}$ and $n i e_{2}$ on the basis of their distinctive featural make-up.

Inspection of the more general circumstances under which identical material is able to surface in adjacent positions is helpful in this regard. ${ }^{20}$ Consider (48) and (49) which illustrate relevant examples from both English and Afrikaans.

(48) a. Die rede dat hyweg is, is dat hy moeg was the reason that he away is is that he tired was "The reason that he's away is that he was tired"21

b. Dat ekdital gedoen het, het hom verstom that I it already done have, have him amazed "That I've already done it amazed him" 
c. Die by by die blom is yslik

the bee by/at the flower is huge

"The bee next to the flower is huge"

(49) a. He will be in in a minute

b. Will Will (i.e., someone called Will) come along?

c. He has learned a lot in his Oriental Studies studies

As $(48 \mathrm{a}, \mathrm{b})$ show particularly clearly, identical elements are allowed to surface adjacent to one another when they are not part of the same intonational phrase. As inspection will reveal, the same is true for all the other examples. What the examples suggest, then, is that the structural configuration in which OCP-style deletion takes place more generally seems to be subject to (at least) two conditions:

(i) that the two phonologically identical elements (two identical prosodic words $/ \omega$ ) be linearly adjacent following Vocabulary Insertion; and

(ii) that these elements be located within the same phonological phrase $(\varphi)$.

Let us investigate whether these conditions also apply to Afrikaans negation.

If clause (b) above is also relevant to doubling and omission in the negation domain, (34) will need to be reformulated along the lines of (50).

(50) Afrikaans Syntactic Haplology mechanism (Take 2)

$\mathrm{Nie}_{2}$ is subject to PF deletion whenever it is sent to Spellout in a position where it will (i) end up (following copy deletion) being the element which is spelled out immediately adjacent to a nie, and (ii) be part of the same prosodic phrase $(\varphi)$ as a nie, i.e., $[\varphi \ldots$ nie nie 2$] \rightarrow$ nie nie $z$

In order to determine whether (50) can in fact capture the Afrikaans negation facts, we will first need to clarify the manner in which prosodic phrases are assumed to be constructed. I adopt Truckenbrodt's (1995) syntax-PF mapping assumptions (cf. also Selkirk 1995), which are presented in (51). 
A. Align-XP, R: Align (XP, R; P, R)

"For each XP, there is a Phonological phrase (P) such that the right edge of XP coincides with the right edge of $\mathrm{P}^{\prime \prime}$

\section{B. Align-XP, L: Align (XP, L; P, L)}

"For each XP, there is a Phonological Phrase (P) such that the left edge of XP coincides with the left edge of $\mathrm{P}^{\prime \prime}$

For Truckenbrodt (1995), A above applies to consistently right-recursive (i.e., head-initial) languages, while B applies to consistently left-recursive (i.e., head-final) languages. For the purposes of this discussion, I will abstract away from the vexed question of how 'headedness' should be captured (via a Head Parameter, as traditionally assumed, or via differences in movement operations, as in LCA-based approaches, or via some combination of (aspects of) these two); all that matters here is that PF be able to "recognise" the position of a head in a given syntactic structure as either initial or final relative to the material contained within the phrase associated with that head. In other words, all that is required in the present context is that PF be able to determine surface head-positioning; syntax-internal 'headedness' is irrelevant. Thus PolP, which is head-initial in the usual (syntax-internal) sense (cf. section 3.3) is in fact head-final as far as PF is concerned because the string on which PF operates is one in which the head of Pol follows all the material contained in the phrase that it heads. Consider (52) by way of illustration (strikethrough once again signifies lower copies which are deactivated at PF and therefore not pronounced).

a. Ek het nie sy $_{1}$ redenasie verstaan nie $_{2}$

I have not his reasoning understood NEG

"I didn't understand his reasoning"

b. $\quad$ [PolP[CP Ek het [TP ek [vP ek [vp nie ${ }_{1}$ [DP sy redenasie ] verstaan] v] het+T]] nie $\left.{ }_{2}\right]$

For expository purposes, (52b) once again reflects relatively conservative assumptions about West Germanic clause structure. Thus (i) VP, $v$ P and TP are all assumed to be head-final in the syntax ( $\mathrm{X}$ is merged so that it follows its complement), and (ii) $\mathrm{V}$ is not assumed to raise (cf. the discussion in section 3.3). Auxiliary het ("have") is indicated as having been merged 
in $\mathrm{T}$ as there appear to be good reasons to assume that temporal auxiliaries in Afrikaans do not raise from $v$ (cf. i.a. the fact that they, unlike their Dutch and German counterparts, are not sensitive to thematic - i.e., $v$ P-related - distinctions like unaccusativity). On the assumption, then, that the mapping algorithm in (51) does indeed pay attention only to "PF headedness" (and not to syntax-internal headedness), it will apply in the following way in Afrikaans.

(i) A will apply to NP, DP, CP and most PP; and

(ii) $\mathrm{B}$ will apply to $\mathrm{VP}, v \mathrm{P}, \mathrm{TP}$ and PolP. ${ }^{22}$

With our mapping assumptions in place, we can briefly confirm that they make the correct predictions as far as the permissibility of the structures in (48-49) is concerned. Consider (5354) where [boldfaced brackets] indicate a syntactic phrase-edge which also maps onto a prosodic phrase-edge.

(53) a. Die rede dat hyweg is, is dat hy moeg was the reason that he away is is that he tired was "The reason that he's away is that he was tired"

$\mathrm{a}^{\prime} . \quad[\mathrm{CP}[\mathrm{DP}$ Die rede $[\mathrm{CP}$ dat hy weg is $]]$ is $[\mathrm{CP}$ dat ...

b. Dat ek dital gedoen het, het hom verstom that I it already done have, have him amazed "That I've already done it amazed him"

b'. $\quad$ [

c. Die by by die blom is yslik the bee by/at the flower is huge "The bee next to the flower is huge"

c'. [DP die [NP by ] [Pp by die blom] $]$ is ...

(54) a. He will be in in a minute

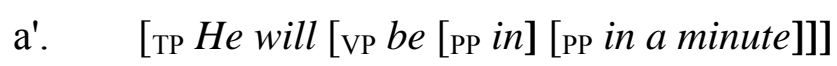

b. Will Will come along?

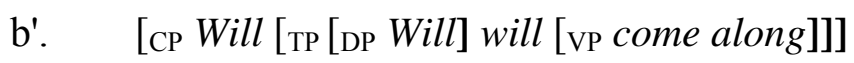




\section{c. He has learned a lot in his Oriental Studies studies \\ c'. $\quad$... [PP in [DP his [DP Oriental Studies] studies]}

As the '-structures indicate, the phonetically identical elements are separated by prosodic boundaries in each case. In (53a), this is a consequence of the fact that CP and DP are headinitial, with the result that they are mapped onto prosodic phrases $(\varphi)$ in accordance with $A$, which in turn ensures that their right edges coincide with the right edge of a $\varphi$; the two ises in (53a) therefore occupy different $\varphi s$ and can thus be spelled out adjacent to one another. The presence of CP- and NP-boundaries ensures the same outcome for the hets and the bys in (53b) and (53c) respectively, while a PP and DP boundaries produce the necessary separations in the English examples in (54). Apparently, then, the syntactic haplology mechanism outlined in (50) is not one which uniquely applies in Afrikaans; it also seems to play a role in accounting for the possibility of identical adjacent elements in English (cf. Biberauer in prep. for further discussion).

Let us now consider whether (50) can also account for the nie-doubling and omission phenomena with which we are primarily concerned in this section.

Consider firstly (46), repeated here as (55) (prosodic phrase-edges once again indicated in bold).

(55) a. Ekwil mense wat nie omgee nie $_{2}$ nie $_{1}$ sien nie 2

I want people who not care NEG not see NEG

"I don't want to see people who don't care"

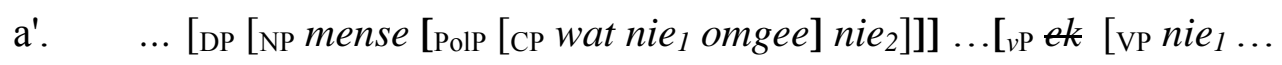

b. Ek sien nie $\boldsymbol{e}_{1}$ die tweede 'nie ${ }_{1}$ ' nie $_{2}$

I see not the second nie NEG

"I don't see the second nie"

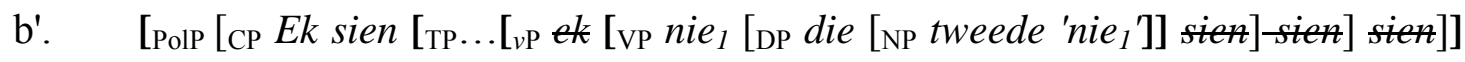
nie $\left._{2}\right]$

As the partial structures indicate, the nies that are spelled out adjacent to one another in both of these examples occupy distinct $\varphi s$ and are therefore predicted by (50) not to be affected by 
OCP-style deletion. In (55a), two $\varphi$-boundaries separate the adjacent nies: the rightward boundary imposed by the fact that the negative relative clause (a PolP) is headed by a headinitial DP (containing an NP) and the leftward boundary mapped onto head-final VP. The same is true for (55b), where the "use-mention" nie $e_{1}$ 's containment within a head-initial NP and DP places it within a $\varphi$ which excludes the final Pol-head. (50) therefore makes the correct predictions as far as these examples are concerned.

The cases of multiple negation-containing (45c) and (47) are slightly more complicated and deserve special attention. Let us firstly consider their single-negation-containing counterpart, (56a), an omission structure for which we had an account under (34) prior to the introduction of the prosodic phrase-mate condition in (50).

\author{
a. Hy sing nie $_{1}$ \\ he sing not \\ "He doesn't sing" \\ b. [ [PolP [CP hy sing [TP hy [vP hy [VP nie $\left.\left.\left.\left.{ }_{1} \operatorname{sing}\right] \operatorname{sing}+v\right] \operatorname{sing}+v+\mathrm{T}\right]\right]$ nie 2$]$
}

If the structure underlying (56a) is indeed that indicated in (56b), the deletion algorithm in (50) would predict that two nies should be spelled out: nie $e_{1}$ and nie 2 are, after all, located in distinct prosodic phrases, leading us to expect $* H y$ sing nie ${ }_{1}$ nie $_{2}$. This structure is, however, ungrammatical, with the result that we can conclude that there must either be a problem with the structural assumptions reflected in (56b) or with the deletion algorithm in (50). In view of the fact that the latter appears to facilitate insight into contexts in which adjacent nies can be spelled out and also, more generally, where OCP effects (fail to) surface, let us inspect the former possibility. Recall that we established on the basis of scrambling and adverb-related facts that nie $e_{1}$ must be adjoined fairly low in the clause structure. Until now, we have simply assumed that this low position is a VP-adjoined one. If nie $e_{1}$ were instead to be $v \mathrm{P}$-adjoined and, specifically, adjoined to the lowest specifier of $v$ - the structure underlying (56a) would be that schematized below.

(56b') [PolP [CP hy sing [TP hy [vP hy nie ${ }_{1}[\mathrm{vP} \operatorname{sing}]$ sing $\left.+v\right]$ sing $\left.\left.+v+\mathrm{T}\right]\right]$ nie 2$]$ 
At first sight, this change would not seem to alter the fact that the prosodic boundaries imposed by (50) will place nie ${ }_{1}$ and nie 2 in distinct prosodic phrases. Two nies should therefore still be spelled out. Notice, however, that the troublesome $\varphi$-boundary (CP's right edge) in fact forms the right edge of a $\varphi$ that will not ultimately contain any overtly realised material. In other words, it marks off the right edge of a unit which will not ultimately play a role in the prosodic structure of the unit that is articulated. It therefore seems reasonable to assume that this superfluous prosodic unit will be deleted before PF sends the structure on to the articulatory-perceptual component (cf. also Nespor and Vogel (1986) who argue that empty categories and their projections do not affect $\varphi$-formation). Let us assume that this is the case and, more specifically, let us assume the following sequence of PF steps after the computational component has sent the structure constructed during Narrow Syntax to PF (see Biberauer in prep. for further discussion).

(i) "first-pass" formation of $\varphi s$ (essentially) on the basis of the mapping algorithm in $(51)$;

(ii) "filling in" of the phonological specifications of the various feature-bundles operated on by syntax. This step entails both spelling out overtly realised copies and suppressing/deleting lower copies;

(iii) "second-pass" refinement of $\varphi s$ : deletion of all $\varphi s$ lacking overtly realised material.

Given (57), we can see that omission structures which, like (56a), do not feature any overtly realised material in the VP-domain will always be subject to the "second-pass" $\varphi$-refinement operation in (iii). Consequently, nie $_{1}$ and nie 2 will always end up in the same $\varphi$, with the result that (50) applies, thereby delivering the correct result: nie $e_{2}$ omission. Crucially, however, this result requires us to view nie ${ }_{1}$, at least in this structure, as a $v \mathrm{P}$-adjoined element.

Consider, now, $(45 \mathrm{~b})$ repeated as $(58 \mathrm{a})$, i.e., a structure in which two nies are permitted to surface adjacent to one another.

a. Hysing NIE nie $_{1}$

he sing not not

"He doesn't not sing" 


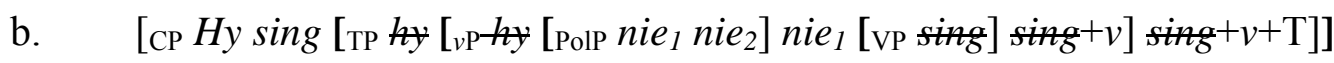

As noted above, interpretive and intonational considerations in particular make it very clear that we are dealing with two adjacent nie $e_{1}$ in this case. More specifically, the first nie scopes over the second nie $e_{1}$, thereby cancelling it out in the manner of double negatives in nonnegative concord languages. Also noted above was the fact that this structure is not in fact prescriptively correct, instantiating the kind of structure that is frequently produced by nonnatives in particular, but also in the spoken language by native-speakers. Native-speakers, however, are fully aware that structures of this kind are not in fact "correct" and are consistently able to produce the prescriptively sanctioned form (cf. (45c)/(60) below) when asked to assess (58a)-type structures. It therefore seems reasonable to view (58a) as a structure which was constructed from a Numeration/Lexical Array which does not include the $n i_{2}$ required in Standard Afrikaans (cf. the examples in (13) above, which likewise are not constructed from Numerations containing $n i e_{2}$ ). The question that we then need to answer is why two nie $e_{1}$ s are able to surface adjacent to one another in this case. If the structure underlying (58a) is indeed that presented in (58b), we would expect only one nie to be spelled out as all three nies are located in the same prosodic phrase. This cannot, then, be the correct structure. Worth noting about (58a), however, is that it is in fact a contrastive focus structure, which is semantically and, barring only additional meanings that may arise as a consequence of the speaker's failure to employ the most concise formulation available (cf. Grice 1975; Sperber and Wilson 1986; etc.), also pragmatically equivalent to the less complex structure in (59).

$$
\begin{aligned}
& \text { Hy sing WEL } \\
& \text { he sing indeed } \\
& \text { "He DOES sing" }
\end{aligned}
$$

Importantly, wel has to be stressed if Hy sing wel is to be interpreted in the relevant contrastive focus sense. This is illustrated in (60).

(60) A: Hy sing nie 1

he sing not

"He doesn't sing" 
B: $\quad$ Hy sing $W E L / * H y$ sing we $^{23}$

he sing indeed

"He DOES sing"

Similarly, the two nie $_{1} \mathrm{~s}$ in the largely equivalent structure also both need to be stressed; thus Hy sing $N_{1} E_{1} N_{1}\left(E_{1} e_{2}\right.$ ), with the way in which this structure was previously represented simply having been intended to reflect the fact that the first nie $e_{1}$ receives greater emphasis than the second. Recall now that nie 2 surfaces as extra element in emphatic structures - cf. (17) and (18) above. More generally, we may assume that emphasised negators differ from their non-emphasised counterparts in featuring an extra PolP "shell". ${ }^{24}$ This would entail that the structure underlying (58b) is in fact $\left(58 b^{\prime}\right)$.

(58b') [

As (58b') shows, viewing the adjacent emphatic nie ${ }_{1} \mathrm{~s}$ as elements which are each surrounded by a PolP "shell" enables us to understand why adjacent nie $e_{1}$ s are possible in this case: as PolP is a head-final phrase, adjacent PolPs will be assigned to separate prosodic phrases, with the result that we expect the $n_{i} e_{2} \mathrm{~S}$ that they contain to be deleted, while the contentful negator is spared. (50) can therefore account for non-standard double nie-containing structures of the

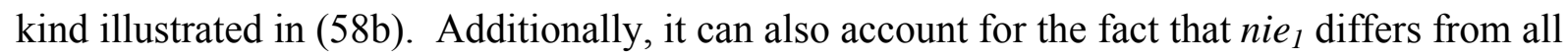
other negation elements in being incompatible with an "extra" (emphasising) nie $e_{2}$ : when nie is emphasised, this can only be signalled intonationally. This is shown in (61).

(61) a. Hy sing nooit nie $e_{2}$ nêrens nie $_{2}$ sulke liedjies nie ${ }_{2}^{25}$

he sing never NEG/nowhere NEG such songs NEG

"He NEVER sings songs like that/He doesn't sing songs like that ANYWHERE"

b. $\quad * H y$ sing nie nie $_{2} / \mathrm{NIE}_{1}$ nie $_{2}$ sulke liedjies nie 2

he sing not NEG/not NEG such songs NEG

c. Hy sing $\mathrm{NIE}_{1}$ sulke liedjies nie $_{2}$

he sing not such songs NEG

"He DOESN'T sing songs like that" 
Furthermore, (50) can also account for the prescriptively correct triple nie-containing structure in (62) below.

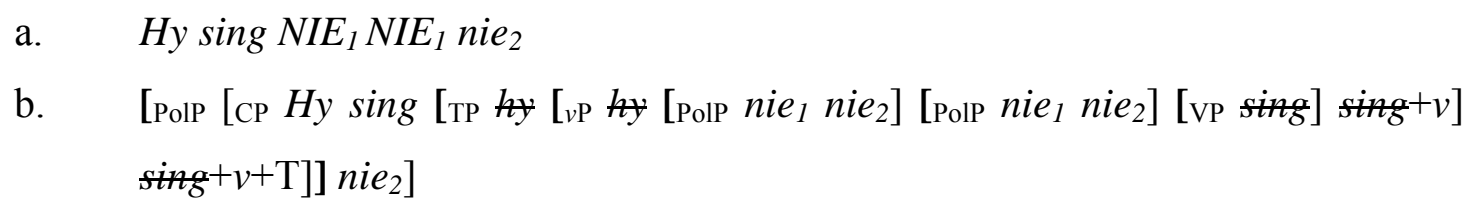

As shown above, the difference between this structure and (58b) is that the latter lacks the prescriptively enforced clause-final nie $e_{2}$. As this element will be assigned to a prosodic phrase distinct from that containing the superficially adjacent nie ${ }_{1}$ (and its associated, but ultimately unrealised $\left.n_{i} e_{2}\right),(50)$ predicts correctly that it will be realised overtly.

Overall, then, it seems that (50) offers us an adequate means of accounting for the negationrelated doubling and omission structures in Afrikaans. Like (34), it predicts that $n_{i} e_{2}$ will always be realised wherever it is not spelled out adjacent to nie $e_{1}$. Additionally, however, it enables us to understand the various circumstances under which two or more nies may be spelled out adjacent to one another. As we have seen above, both adjacent nie ${ }_{1}$ - and adjacent $n i e_{1}$ and nie $e_{2}$-strings are possible in Afrikaans. Neither of these facts falls out straightforwardly from (34), but both can be accounted for if we require adjacent nies to be spelled out in distinct prosodic phrases, as stated in (50). This requirement would also seem to hold more generally of identical adjacent elements, not only in Afrikaans, but also in English and maybe also beyond (cf. Biberauer in prep. for further discussion).

\section{Conclusion}

The empirical focus of this paper has been the doubling and omission phenomena that surface in the Afrikaans negation context. I have argued that careful investigation of the relevant structures can uncover facts about their structure and about Afrikaans clause structure more generally that would not otherwise be apparent. Thus we have, for example, seen how the presence vs. absence of $n i e_{2}$ appears to be conditioned, not by a language-specific, construction-specific haplology mechanism of the kind originally outlined in (34), but instead by an apparently more generally valid PF-deletion mechanism which is specifically guided by a syntax-PF mapping algorithm that has previously been argued to apply crosslinguistically. 
The systematic manner in which (50) enables one to predict not only the (non-)realisation of $n e_{2}$, but also the (im)possibility of adjacent nies shows that it is correct, as Den Besten (1986) originally implied, to maintain the view that Afrikaans is a strict negative concord language. This, then, resolves the language's until now rather problematic status in the typological context.

At a more specific level, the presence vs. absence of nie $e_{2}$ also serves as a clause-structure diagnostic, giving us insights into the positioning of various non-negative elements ("scrambled" vs. "non-scrambled" objects, adverbs, verbs, etc.) and opening up the possibility of adjudicating the merits of alternative clause-structure proposals (i.a. whether a consistently head-initial analysis of Afrikaans clause structure is feasible, contra Haegeman (1995: 300), Note 5). What is already clear at this stage is that:

(i) Afrikaans exhibits Germanic-style scrambling, despite its morphological impoverishment (lack of case-marking; cf. proposals dating back to at least Sapir (1921) in terms of which the availability of scrambling is directly tied to the presence of case-marking);

(ii) adverbs in Afrikaans at least do not occupy fixed specifier positions, as assumed by Cinque (1999) and others;

(iii) particles associated with particle verbs remain VP-internal as these structures necessarily contain two nies (cf. Hy kom nie $\boldsymbol{n}_{1}$ in $\boldsymbol{n i e}_{2}$ - "He comes not in NEG", i.e., He doesn't come in); and

(iv) clause-final nie $e_{2}$ is not strictly a clause-related element; it is a polarity head which may also optionally create a "shell" around non-clausal XPs (DPs, PPs, etc.). As Afrikaans is $\mathrm{NC}$ at the clausal level, i.e., $n^{2} e_{2}$ is obligatory, it simply serves an "agreeing" function in this context. In non-clausal contexts, by contrast, it is only optionally present and can therefore contribute what may in fact be its "original" (i.e., pregrammaticalisation) meaning, namely polarity-reinforcing emphasis.

Finally, the proposed analysis also appears to facilitate insights at a more general level into the internal workings of PF (see (57) and cf. Biberauer in prep. for more discussion). As discussed in section 3.4, the haplological mechanism proposed here entails that PF operate in a very specific manner, with certain operations necessarily preceding others. The proposals 
made here therefore also make a contribution to the current debate about the nature and architecture of PF and, more specifically, about the nature and variety of PF-deletion operations.

\section{Notes}

* Grateful thanks to the following for their helpful questions, comments and suggestions: the audience at the Cambridge SyntaxLab meeting held on 14 March 2006; the audience at the Syntactic Doubling in European Dialects meeting held in Amsterdam (16-18 March 2006), particularly Sjef Barbiers, Hans Bennis, Vina Tsakali, Cecilia Poletto, Helmut Weiß and Hedde Zeijlstra; the audience at the 21st Comparative Germanic Syntax Workshop (CGSW21) held in Santa Cruz, California (30 March-2 April 2006), particularly Vera Lee-Schoenfeld, Peter Svenonius, Jan-Wouter Zwart and Hedde Zeijlstra (again); and two very helpful SPiL reviewers. Thanks also to André Pretorius for indulging my "sudden odd uncertainty" about some of the Afrikaans data presented here. The usual disclaimers apply. This work is supported by AHRC project No. R280168 ("Null Subjects and the Structure of Parametric Variation"; Principal Investigator: Anders Holmberg).

1. Agreementless glosses throughout the paper reflect the absence of verbal agreement on the verbs concerned.

2. Cf. Zeijlstra (2006) for detailed discussion of the difference between NC and DN. There are, of course, NC varieties of Dutch, most famously perhaps West Flemish (cf. Haegeman 1995 for discussion).

3. I will remain agnostic in this paper on the much-debated question of whether scrambling is in fact a movement-derived or a base-generated phenomenon (see Richards 2004 for recent discussion). A scrambled order should thus simply be understood as one in which the object is located to the left of the position in which it surfaces in a structure in which scrambling has not taken place.

4. As pointed out by an anonymous reviewer, sulke in (12b) may or may not be emphasised; emphasis on the final nie is, however, obligatory.

5. Note that Oosthuizen (1998: 76ff) analyses this reinforcing nie as nie $e_{1}$, but does not offer specific argumentation in favour of this analysis. In view of the clear parallelisms between this "reinforcing" nie and the clause-final negator - neither contribute 
independent negative semantics - and the equally evident lack of parallelisms between the "extra" nie and nie ${ }_{1}$, the analysis proposed in Biberauer (2006) and also adopted here seems straightforwardly preferable.

6. The structure in (20b) can, of course, be further reinforced by employing an "extra" nie 2 - thus Hy het niks nie 2 geld nie $e_{2}$ - as discussed for examples (17-18).

7. The manner in which the VP is represented here is not in accordance with Bare Phrase Structure assumptions, in the context of which vacuous projections (here: V and $V^{\prime}$ ) and a head-terminal distinction do not exist (cf. Chomsky 1995). The aim here is simply to provide a clear representation of the VP-adjunct status of nie ${ }_{1}$. In subsequent trees, superfluous intermediate structure will be omitted. Where intermediate projections are required (e.g., where a specifier is projected), they will, however, continue to be labelled as bar-level nodes $\left(\mathrm{X}^{\prime}\right)$ to facilitate easier discrimination from the relevant maximal projections.

8. As discussed in Biberauer (2006), the evidence that has previously been adduced in favour of the idea that Afrikaans clause structure includes a NegP which specifically attracts negative elements (cf. Haegeman (1995: 179), who follows Robbers (1992)) turns out to be significantly more complex than usually thought.

9. The following examples illustrate that the neutral position for $n i_{1}$ is in fact to the left of both internal arguments wherever we are dealing with a ditransitive verb (cf. (i)); when the indirect object surfaces to the left of $n_{i} e_{1}$ as in (ii), it receives the same nonrhematic interpretation associated with scrambling more generally:

$$
\text { ... dat ek nie }{ }_{1} \text { vir Jan boeke koop nie } 2
$$
that I not for Jan books buy NEG

"... that I am not buying books for Jan" (all-rhematic)

$$
\text { ... dat ek vir JAN nie }{ }_{1} \text { boeke koop nie } 2
$$
that I for Jan not books buy NEG "... that I am not buying Jan (specifically) books"

10. I leave aside here the very interesting question of the precise relationship between PolP and CP, but one possibility could be that Pol is in fact one of the hierarchically organised features associated with the $\mathrm{C}$ phase-head, which may be independently realised as a distinct functional projection whenever the Pol-head is valued negative. Whether Pol projects as a separate projection in positive polarity contexts is also an interesting question: although Afrikaans does not lexically encode a positive polarity 
marker (I leave aside here "true" positive polarity markers like wel (roughly "in fact"), which appear to be the positive counterpart of the "true" negators), there does appear to be at least one structure which serves a specifically positive polarity-affirming function: predicate doubling of the kind illustrated in (i):

\section{Luister sal hy luister!}

listen shall he listen

"He will jolly well listen"

Structures like (i) are emphatically positive and are incompatible with negation as illustrated in (ii):

(ii) $\quad *$ Luister sal hy nie ${ }_{1}$ luister nie 2

Interestingly, numerous unrelated languages appear to feature emphatically positive structures involving verb-doubling of the kind illustrated in (i) - cf. i.a. Koopman (1984) on Vata, Kandybowicz (2006) on Nupe, Martins (2007) on European Portuguese, Petronio (1993) on American Sign Language (ASL) and Quadros (1999) on Brazilian Sign Language (LSB). To the best of my knowledge, these structures are always incompatible with the overt expression of negation and, if Kandybowicz's appealing (2006) analysis of the Nupe verb-doubling structure is correct, the reason for this may well be that verb-doubling structures require (a positively specified) Pol to be projected separately in positive polarity contexts too. I leave the details of this question to future research.

11. Cf. i.a. Horvath (2005) on clause pied-piping generally; Hermon (1985), De Urbina (1990), Richards (1997), Bhatt (1999), and Simpson and Bhattacharya (2000, 2003) on clausal pied-piping in wh-interrogative contexts; Hallman (2004) on V2 and Vfinal orders in Germanic; Holmberg (2001, 2005), Aboh (2004), and Munaro and Poletto (2004) on clause-final clause-typers in (at the clausal level) otherwise headinitial languages, and also Kandybowicz (2006) on polarity-related clausal pied-piping in Nupe, which bears an uncanny resemblance to that proposed for Afrikaans here.

12. This example, then, shows that the reinforcing function that $n_{i} e_{2}$ sometimes plays (cf. (17-18) above) is limited to contexts in which it genuinely surfaces as an "extra" element over and above the "true" negator and its associated nie $e_{2}$ : in (33c), this is clearly not the case as the structure features only a single nie. It should also be noted that the fact that native-speakers judge structures like (33c) to be "missing something" in just the way they do when non-natives omit final nie 2 (cf. the examples in (13)) 
further underlines the correctness of viewing Afrikaans as a strict negative concord language which employs a deletion-under-adjacency filter of roughly the kind sketched out by Den Besten: as soon as nie ${ }_{1}$ is replaced by a phonetically distinct "true" negator which would not be subject to the haplological filter (geensins in this case), nie $_{2}$ surfaces, as one would have expected in a strict negative concord language.

13. Cf. Neeleman and Van de Koot (2005) for overview discussion of syntactic haplology and its relation to the Obligatory Contour Principle/OCP Effects that have frequently been noted in phonology.

14. Note that the analysis proposed here would also be compatible with an analysis which assumes V-raising to a higher verbal head, e.g. $v$ or T. If $v \mathrm{P}$ and TP are head-final, a raised verb will still intervene between $n i e_{1}$ and $n i e_{2}$, thereby leading us to expect the observed nie-doubling structure. If $v \mathrm{P}$ and $\mathrm{TP}$ are head-initial, as numerous researchers have assumed since Zwart (1993), we would also have to assume that the VP- and $v$ P-material that surfaces to the left of the verb undergoes raising into a higher domain (to ensure that the verb is spelled out to the right of all material other than $n e_{2}$ ). In this case too, then, we would expect two nies to be spelled out as the raised verb will still intervene between (raised) $n i e_{1}$ and nie $e_{2}$. Nie-doubling vs. omission therefore cannot serve as an independent $\mathrm{V}$-movement diagnostic.

15. Further evidence in favour of the correctness of the "information"-oriented analysis presented here would seem to come from non-standard spoken Afrikaans in which structures like the following are permissible:

(i) Ek verstaan nie $_{1} *(v i r)$ hom/ haar nie $_{2}$ (= SA Ek verstaan hom/haar nie 1 )

I understand not for him/her NEG

"I don't understand him"

As shown above, a pronominal object may appear in a structure containing two nies iff it is introduced by vir, i.e., the element that has been convincingly argued to function as a compensatory "rheme-marker" in contexts where an object has failed to undergo "old information"-driven scrambling - cf. the ungrammaticality of vir in (ii) where the pronoun has undergone the customary defocusing movement (and see Molnárfi (1999) for more detailed discussion of vir's "rheme-marking" status):

(ii) Ekverstaan (*vir) hom nie $_{1}$

I understand for him not

"I don't understand him" 
16. Note that there is in fact some dispute in the literature as to the exact adjunction site of the adverbs traditionally designated VP-adverbs. Thus numerous authors (cf. i.a. Adger and Tsoulas 2000 and Göbbel 2007) have proposed that these adverbs are in fact low $v P$-adverbs. If this were also to be the case in Afrikaans, these adverbs and nie $_{1}$ could therefore be competing for the lowest adjunction site within $v \mathrm{P}$. We return to this matter in section 3.4 .

17. Interestingly, the nie-placement diagnostics that we are considering in this section suggest that so-called wh-in situ structures in Afrikaans do not consistently involve in situ wh-elements. Consider the non-fronted counterparts of $(42 \mathrm{~b}, \mathrm{c})$ :

Jan lees WAT nie 1 ?!

John read what not

"John doesn't read WHAT?!"

\section{?Jan lees nie ${ }_{1}$ WAT nie 2 ?!}

(ii) Jy verstaan WAAROM nie ? $^{\text {? }}$

you understand why not

"You don't understand WHY?!"

*Jy verstaan nie WAAROM nie $_{2}$ ?!

As indicated above, the typical "echo question" interpretation usually associated with wh-in situ structures falls out from single-nie-containing structures in Afrikaans; structures with two nies (i.e., those in which the wh-element has remained in situ within VP) are either ungrammatical as in (ii) or, as in (i), not the most natural "echo question" in typical "echo" contexts, i.e., those in which a statement including the missing piece of information has preceded the "echo" question and is therefore "old information" (this latter fact seems to be replicated in German). I leave the details surrounding the structure of Afrikaans "echo" questions and what they may signal about "echo" questions more generally for further research.

18. Here the second nie 1 may be stressed, but it need not be.

19. Thanks to an anonymous reviewer for mentioning this example.

20. I leave aside here reduplication, which is famously quite productive in Afrikaans (cf. Botha 1988). The way (34) is stated, it is clear that it applies after Vocabulary Insertion and therefore cannot "look inside" the structure of individual lexical items. 
As such, reduplicated lexical items automatically fall outside the scope of this mechanism.

21. Cf. also the English The thing is is that ... phenomenon (cf. Massam 1999). Although the structure in question is prescriptively proscribed, it is very prevalent in many spoken varieties of North American and British English and the crucial point for our purposes is that there is no OCP-style mechanism operative at PF which precludes the possibility of the two ises being realised adjacent to one another.

22. Note that in assuming that not only lexical, but also functional categories can define ps, I depart from Selkirk (1995), who proposes that only the former may do so. More research is required to determine whether a given category's "visibility" to the mapping algorithm in (51) is universally fixed or subject to parametric variation. As will become clear from subsequent discussion in the main text, at least C's status as a $\varphi$-definer appears to be crucial in Afrikaans. Also relevant to this issue is the status of labels like $C, T, D$, etc. See Biberauer (in prep.) for further discussion.

23. As wel is a positive-polarity-emphasizing element, it is in fact always obligatory that some element in the structure in which it occurs be emphasised. Thus:

(i) Hy sing WEL

he sing indeed = "He DOES sing (contrary to what you said before)"

(ii) HY sing wel

he sing indeed = "HE sings (even if others don't)"

(iii) Hy SING wel

he sing indeed = "He does SING (even if he doesn't play any instruments)"

24. Further investigation of Afrikaans negation structures suggests the correctness of the idea that Pol is not exclusively C-related - in the sense of specifically being clauserelated - in this language. Recall, for example, the fact that "extra" nie 2 s may serve a (polarity-)reinforcing function in spoken Afrikaans (cf. (17-18) above). More generally, it seems that all focusable XPs are compatible with an overtly realised Polhead. The following examples illustrate:

(i) $\mathrm{Nie}_{1}$ die BOEK nie 2 , maar die KOERANT wil ek hê not the book not, but the newspaper want I have "Not the book, but the newspaper is what I want"

(ii) A: Watter ene wil jy hê? Die groene of die rooie? which one want you have the green or the red 
"Which one do you want? The green or the red?"

B: Nie $_{1}$ die groene nie ${ }_{2}$ !

not the green NEG

"Not the green one!"

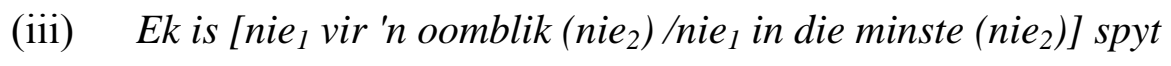

$\mathrm{I}$ is not for a moment NEG/not in the least NEG sorry

"I am not sorry for a minute/I am not in the least sorry"

25. It should be noted that these structures are colloquial ones which native-speakers would readily employ in the spoken language, but never in writing.

\section{References}

Aboh, E. 2004. The morphosyntax of complement-head sequences: clause structure and word order patterns in Kwa. Oxford: Oxford University Press.

Adger, D. and G. Tsoulas. 2000. Aspect and lower VP-adverbials. In A. Alexiadou and P. Svenonius (eds). Adverbs and adjunction. Potsdam: University of Potsdam. pp. 1-18.

Bell, A. 2004a. How N-words move: bipartite negation and 'Split-NegP'. In A. Breitbarth and H. van Riemsdijk (eds). Triggers. Amsterdam: Mouton de Gruyter. pp. 77-114.

Bell, A. 2004b. Bipartite negation and the fine structure of the negative phrase. Doctoral dissertation, Cornell University.

Bhatt, R. 1999. Verb movement and the syntax of Kashmiri. Dordrecht: Kluwer.

Biberauer, T. 2003. Verb Second (V2) in Afrikaans: A Minimalist analysis of word-order variation. Doctoral dissertation, Cambridge University.

Biberauer, T. 2006. Afrikaans negation: A crosslinguistically motivated analysis. Manuscript, University of Cambridge.

Biberauer, T. (in prep.) Approaching Spellout: Perspectives from "missing" elements.

Biberauer, T. and I. Roberts. 2005. Changing EPP-parameters in the history of English: Accounting for variation and change. English Language and Linguistics 9(1): 5-46.

Botha, R. 1988. Form and meaning in word formation: A study of Afrikaans. Cambridge: Cambridge University Press.

Cardinaletti, A. and M. Starke. 1996. Deficient pronouns: A view from Germanic. In H. Thráinsson, S. Epstein, and S. Peter (eds). Studies in comparative Germanic syntax 2. Dordrecht: Kluwer. pp. 21-65. 
Chomsky, N. 1995. Bare phrase structure. In G. Webelhuth (ed). Government and binding theory and the Minimalist program. Oxford: Blackwell. pp. 383-439.

Chomsky, N. 2000. Minimalist inquiries: The framework. In R. Martin, D. Michaels, and J. Uriagereka (eds). Step by step. Essays on Minimalist syntax in honor of Howard Lasnik. Cambridge: MIT Press. pp. 89-156.

Cinque, G. 1991. A null theory of phrase and compound stress. Linguistic Inquiry 24: 239297.

Cinque, G. 1999. Adverbs and functional heads: A cross-linguistic perspective. Oxford: Oxford University Press.

Déchaine, R. and M. Wiltschko. 2003. Negation at the left periphery. Evidence from Algonquian and Salish. In L. Carmichael, C-H. Huang, and V. Samiian (eds). Proceedings of WECOL 2001. Fresno: CSU Fresno. pp. 104-117.

Den Besten, H. 1977/1983. On the interaction of root transformations and lexical deletive rules. In W. Abraham (ed). 1983. On the formal syntax of the West Germania. Amsterdam: Benjamins. pp. 47-131.

Den Besten. H. 1986. Double negation and the genesis of Afrikaans. In P. Muysken and N. Smith (eds). Substrata versus universals in creole genesis. Amsterdam: Benjamins. pp. $185-230$.

De Urbina, J. 1990. Operator feature percolation and clausal pied piping. In L. Cheng and H. Demirdache (eds). Papers on wh movement. Cambridge: MIT Press. pp. 193-208.

Diesing, M. 1992. Indefinites. Cambridge: MIT Press.

Donaldson, B. 1993. A grammar of Afrikaans. New York: Mouton de Gruyter.

Giannakidou, A. 1999. Affective dependencies. Linguistics and Philosophy 22: 367-421.

Giannakidou, A. 2005. $N$-words and negative concord. In M. Everaert and H. van Riemsdijk (eds). The Blackwell companion to syntax 3. Oxford: Blackwell. pp. 327-391.

Göbbel, E. 2007. Focus and marked positions for VP adverbs. In S. Winkler and K. Schwabe (eds). On information structure, meaning and form. Amsterdam: Benjamins. pp. 275300.

Grice, H. 1975. Logic and conversation. In P. Cole and J. Morgan (eds). Syntax and semantics. New York: Academic Press. pp. 41-58.

Haegeman, L. 1995. The syntax of negation. Cambridge: Cambridge University Press. 
Halle, M. and A. Marantz 1993. Distributed morphology and the pieces of inflection. In K. Hale and S. Keyser (eds). The view from Building 20. Cambridge: MIT Press. pp. 111176.

Hallman, P. 2004. On the derivation of verb-final and its relation to Verb-second. Manuscript, McGill University. http://individual.utoronto.ca/hallman/Verb_Second.pdf.

Hermon, G. 1985. Syntactic modularity. Dordrecht: Foris.

Holmberg, A. 2001. The syntax of yes and no in Finnish. Studia Linguistica 55: 141-175.

Holmberg, A. 2005. Null subjects and polarity focus. Proceedings of NELS 35: 21-42.

Horn, L. 2002. Assertoric inertia and NPI licensing. In M. Andronis, E. Debenport, A. Pycha, and K. Yoshimura (eds). Proceedings of CLS 38(2): The Panels. pp. 55-82.

Horvath, J. 2005. Pied-piping. In M. Everaert and H. van Riemsdijk (eds). The Blackwell companion to syntax 2. Oxford: Blackwell. pp. 569-631.

Kahnemuyipour, A. 2005. Towards a phase-based theory of sentential stress. In M. McGinnis and N. Richards (eds). Perspectives on phases: Proceedings of the Workshop on EPP and Phases. MIT Working Papers in Linguistics Series.

Kandybowicz, J. 2006. Conditions on multiple copy spell-out and the syntax-phonology interface. Doctoral dissertation, UCLA.

Kiparsky, C. and P. Kiparsky 1971. Fact. In D. Steinberg and L. Jakobovits (eds). Semantics. An interdisciplinary reader. Cambridge: Cambridge University Press. pp. 345-369.

Koopman, H. 1984. The syntax of verbs. Dordrecht: Foris.

Laka, I. 1990. Negation in syntax. Doctoral dissertation, MIT.

Laka, I. 1994. On the syntax of negation. New York: Garland.

Leben, W. 1973. Suprasegmental phonology. Doctoral dissertation, MIT.

Martins, A-M. 2007. Double realization of verbal copies in European Portuguese emphatic affirmation. In N. Corver and J. Nunes (eds). The copy theory of movement on the PF side. Amsterdam: Benjamins. pp. 77-118.

Massam, D. 1999. Thing is construction: The thing is, is what's the right analysis? English Language and Linguistics 3(2): 335-352.

Molnárfi, L. 1999. Zur Diskurskomponente in der Sprechsprache: vir als Rhemamarkierer im Afrikaans. Folia Linguistica 33(1): 75-102.

Molnárfi, L. 2002. Die Negationsklammer im Afrikaans: Mehrfachnegation aus formaler und funktionaler Sicht. In W. Abraham and J-W. Zwart (eds). Issues in formal German(ic) typology. Amsterdam: Benjamins. pp. 223-261. 
Molnárfi, L. 2004. On the interpretation of multiple negation in spoken and written Afrikaans. In A. ter Meulen and W. Abraham (eds). The composition of meaning. Amsterdam: Benjamins. pp. 145-167.

Munaro, N. and C. Poletto 2004. Sentential particles and clausal typing in the Veneto dialects. http://www.unive.it/media/allegato/download/Lingue/Materiale_didattico_ Poletto/ pubblicazioni/SPforDEWvolume.pdf.

Nairn, R., C. Condoravdi, and L. Karttunen. 2006. Computing relative polarity for textual inference. Manuscript, PARC Research Center.

Neeleman, A. and H. van de Koot. 2005. Syntactic haplology. In M. Everaert and H. van Riemsdijk (eds). The Blackwell companion to syntax. Oxford: Blackwell. pp. 685-710.

Neeleman, A. and F. Weerman. 1999. Flexible syntax. A theory of case and arguments. Dordrecht: Kluwer.

Nespor, M. and I. Vogel. 1986. Prosodic phonology. Dordrecht: Foris.

Nunes, J. 2004. Linearization of chains and sideward movement. Cambridge: MIT Press.

Oosthuizen, J. 1998. The final nie in Afrikaans negative sentences. Stellenbosch Papers in Linguistics 31: 61-94.

Ouali, H. 2003. Sentential negation in Berber. A comparative study. In J. Mugany (ed). Linguistic description: Typology and representation of African languages. Trenton: World Press. pp. 243-256.

Ouali, H. 2005. Negation and negative polarity items in Berber. In M. Ettlinger, N. Fleischer, and M. Park-Doob (eds). Proceedings of the $20^{\text {th }}$ Annual Meeting of the Berkeley Linguistics Society. pp. 330-340.

Ouali, H. 2006. Unifying agreement relations: A minimalist analysis of Berber. Doctoral dissertation, University of Michigan.

Petronio, K. 1993. Clause structure in American Sign Language. Doctoral dissertation, University of Washington.

Quadros, R. 1999. Phrase structure in Brazilian Sign Language. Doctoral dissertation, Pontifícia Universidade Católica do Rio Grande do Sul.

Richards, M. 2004. Object shift and scrambling in North and West Germanic: A case study in symmetrical syntax. Doctoral dissertation, Cambridge University.

Richards, N. 1997. Movement in Language. Oxford: Oxford University Press.

Robbers, K. 1992. Properties of negation in Afrikaans and Italian. In R. Bok-Bennema and R. van Hout (eds). Linguistics in the Netherlands. Amsterdam: Benjamins. pp. 223-234. 
Roberge, P. 2000. Etymological opacity, hybridization, and the Afrikaans brace negation. American Journal of Germanic Linguistics and Literatures 12(1): 101-176.

Sapir, E. 1921. Language. An introduction to the study of speech. New York: Harcourt Brace Jovanovich.

Selkirk, E. 1995. The prosodic structure of function words. In J. Beckman, L. Dickey, and S. Urbanczyk (eds). Papers in Optimality Theory. Amherst: GLSA. pp. 439-469.

Simpson, A. and T. Bhattacharya. 2000. Feature-percolation, pied piping and transparency. Manuscript, SOAS and UCL. http://mercury.soas.ac.uk/Linguistics/papers/whep.pdf.

Simpson, A. and T. Bhattacharya. 2003. Obligatory overt wh-movement in a wh-in-situ language. Linguistic Inquiry 34(1): 127-142.

Sperber, D. and D. Wilson 1986. Relevance: communication and cognition. Oxford: Blackwell.

Truckenbrodt, H. 1995. On the relation between syntactic phrases and phonological phrases. Linguistic Inquiry 30(2): 219-255.

Vicente, L. 2006. Negative short replies in Spanish. Manuscript, ULCL.

Vikner, S. 2005. Immobile complex verbs in Germanic. Journal of Comparative Germanic Linguistics 8: 83-115.

Waher, H. 1978. Die probleem van die bereik van die ontkenning met spesiale verwysing na Afrikaans. Doctoral dissertation, University of Cape Town.

Waher, H. 1983. Die tweede ontkenningspartikel in Afrikaans. In A. Sinclair (ed). G.S. Nienhaber - 'n huldeblyk. Cape Town: UWK Printers. pp. 695-703.

Waher, H. 1988. Eenders of anders? 'n Vergelyking tussen die ontkenning in Afrikaans en Afro-Portugees. South African Journal of Linguistics 6(1): 109-127.

Zeijlstra, H. 2004. Sentential negation and negative concord. Utrecht: LOT dissertations series.

Zeijlstra, H. 2006. Negative doubling in non-negative concord languages. Paper presented at Doubling in European Dialects (Amsterdam) and CGSW21 (UCSC). http://www. meertens knaw.nl/projecten/edisyn/.

Zubizaretta, M-L. 1998. Prosody, focus, and word order. Cambridge: MIT Press.

Zwart, J-W. 1993. Dutch syntax:A minimalist approach. Doctoral dissertation, University of Groningen. 